\title{
Late middle Miocene Konan flora from northern Hokkaido, Japan
}

\author{
ATSUFUMI NARITA $^{1 *}$, ATSUSHI YABE ${ }^{2}$, KAZUHIKO UEMURA $^{2}$ \\ and MIDORI MATSUMOTO ${ }^{3}$
}

\author{
${ }^{1}$ Sapporo Moiwa High School, 3-2-1-1, Kawazoe, Minami-ku, Sapporo, Hokkaido, 005-0803, Japan; \\ e-mail: atsufumi.narita@sapporo-c.ed.jp, creta90ma@yahoo.co.jp \\ ${ }^{2}$ Department of Geology and Paleontology, National Museum of Nature and Science, 4-1-1, Amakubo, Tsukuba, \\ Ibaraki, 305-0005, Japan; e-mail: yabeatsu@kahaku.go.jp (AY), kzhuemura@hotmail.com (KU) \\ ${ }^{3}$ 1551-82, Miyanogi-cho, Inage-ku, Chiba, 263-0054, Japan; e-mail: mido-55-mido@nifty.com
}

Received 28 March; accepted for publication 29 September 2020

\begin{abstract}
Plant macrofossils from the upper middle Miocene Konan Tuffaceous Sandstone and Mudstone Member of the Bifuka Formation, known as the Konan flora, northwest of Shibetsu City, Hokkaido, Japan, were taxonomically revised. A total of 31 taxa were recognized, which were assigned to 14 families and 19 genera, including a new fossil species, Salix palaeofutura sp. nov. The Konan flora includes three taxa of evergreen conifers, one perennial monocot herb and 27 deciduous dicots. The most abundant and common species were Fagus palaeojaponica, Acer subcarpinifolium, Acer protojaponicum, Picea sp. A and Cercidiphyllum crenatum, in addition to a number of species of the Betulaceae and Salicaceae. From the absence of evergreen angiosperms as well as the common occurrence of Fagus palaeojaponica, Picea, Acer and Betulaceae species, this flora was comparable to that seen in the modern Mixed Northern Hardwood Forest of East Asia, which is distributed in northernmost Honshu and extends toward lowland Hokkaido. On the basis of floral features, mode of occurrence, and the lithology of plant-bearing beds, the Konan flora was deemed to represent mountain to riverside vegetation with humid and cool temperate climatic conditions. In contrast to the early to late Miocene floras in Japan, the Konan flora belongs to the late Miocene-Pliocene Mitoku-type flora, with a few relict species from the early Miocene. The Konan flora represents one of the earliest occurrences of this type of flora, suggesting that floral modernization was initiated much earlier in areas with humid and cool temperate climate than previously thought.
\end{abstract}

KEYWORDS: Plant macrofossil, Konan flora, cool temperate climate, Hokkaido, Mitoku-type flora, late middle Miocene

\section{INTRODUCTION}

The Japanese Islands contain a unique vegetation which includes a number of endemic species such as Fagus crenata Blume, Fagus japonica Maxim., Acer japonicum Thunb. and Acer carpinifolium Sieb. \& Zucc. (e.g. Kato and Ebihara, 2011). The extant vegetation of the Japanese Islands differs from the vegetation distributed in either Southern Primorye or the Korean Peninsula, primarily due to differences in climatic conditions (e.g. Shimizu, 2014). Although all these areas are affected by the

\footnotetext{
Corresponding author
}

Asian monsoon system, the Japanese Islands possess higher humidity and milder temperatures than the Eurasian continent. This condition is considered to have developed due to the rifting and opening of the Japan Sea during the early Miocene (Pavlyutkin et al., 2016).

Changes in the Neogene flora of Japan were summarized by Tanai (1961), who recognized six floral types by their floristic composition and geological age: Ainoura-type (latest Oligoceneearly-early Miocene), Aniai-type (early-early Miocene), Daijima-type (late-early-early-middle Miocene), Mitoku-type (late Miocene-early 
Pliocene), Shinjo-type (Pliocene) and Akashitype (Pliocene-Pleistocene). The transition between the Daijima-type and Mitoku-type flora is not well understood, because plantbearing terrestrial strata of the middle Miocene are scarce in Japan (Uemura, 1991).

The Nayoro area of northern Hokkaido is an exceptional place in which late middle to late Miocene plant-bearing terrestrial deposits are well distributed. Uemura (1991) initially reported seven species of plant fossils from the Bifuka Formation, among which Fagus palaeojaponica Tanai \& Onoe was dominant. On the basis of their field survey and fossil collection at the Bifuka Formation, Narita et al. (2012) reported 38 taxa distributed among 17 families and 24 genera; they discussed floristic features and climatic conditions inferred from the physiognomic characteristics of the flora, and quantitatively analyzed these features using CLAMP (Climate Leaf Analysis Multivariate Program; Wolfe, 1995). They concluded that the Konan flora was comparable to Mixed Northern Hardwood Forest (Wolfe, 1979), which is associated with a wet, cool temperate climate similar to that seen today in Hokkaido or northern Honshu, Japan. They further suggested that this assemblage could be compared with the Mitoku-type flora of the late MiocenePliocene. However, a detailed description of its constituent fossils has not yet been published.

In this study we re-examined all of the Konan flora specimens, described those requiring systematic descriptions, and proposed one new fossil species, Salix palaeofutura. We evaluated the Konan flora to infer regional floristic changes that occurred in Hokkaido (northernmost Japan) and compared them with those that occurred in Honshu, the Korean Peninsula and Russian Primorye.

\section{GEOLOGICAL SETTING}

Middle to Upper Miocene terrestrial deposits are widely distributed in the Nayoro area of northern Hokkaido (Imanishi, 1956; Hashimoto et al., 1965; Takahashi et al., 1971; Tanai et al., 1981, 1992; Oka, 1994; Narita et al., 2012, 2017). A large-scale north-south to northwest-southeast syncline structure, the Teshio and Yayoi synclines, has been recognized in the Nayoro basin, with minor anticline and syncline axes in the same direction (Narita et al., 2012; Fig. 1). The terrestrial deposits are divided into the Bifuka and Kawanishi formations in ascending order. The Bifuka Formation unconformably overlies the lower Middle Miocene Kotanbetsu and Shimaroppu formations of marine origin; it consists mainly of tuff breccia and partly contains tuffaceous sandstone and mudstone, the latter of which are collectively referred to as the Konan Tuffaceous Sandstone and Mudstone Member. This member is estimated to be $50 \mathrm{~m}$ thick and is distributed along the Onnebetsu River in northwestern Shibetsu City, located to the west of the Nayoro Basin (Fig. 1). The lower part of the member is comprised of parallel laminated mudstone, while the upper part comprises trough cross-stratified fine- to coarse-grained sandstones. Plant macrofossils are present in the parallel laminated mudstone of the lower part of the member.

The K-Ar ages of the tuff breccia and andesite of the main part of the Bifuka Formation have been determined to be $13.3 \pm 0.9 \mathrm{Ma}$ (Shibata and Tanai, 1982) and $11.8 \pm 0.6 \mathrm{Ma}$ (Goto et al., 1995). The Tachikaraushinai and Chiepotsunai formations, which are stratigraphically comparable strata, have been dated using the K-Ar method and are determined to be $13.7 \pm 0.7$, $13.8 \pm 0.9 \mathrm{Ma}$ (Shibata et al., 1981) or $12.4 \pm 0.7$ Ma (Shibata and Tanai, 1982). Since the uppermost portion of the Kotanbetsu Formation yields diatom fossils indicating a NPD4A zone (15.9-14.9 Ma: Yanagisawa and Akiba, 1998), the age of the Bifuka Formation has been well confined to the late Middle Miocene.

\section{MATERIALS AND METHODS}

The materials used in this study were collected from two horizons in a single locality (Kn-1 and Kn-2) of the Konan Tuffaceous Sandstone and Mudstone Member of the Bifuka Formation. The locality is the same as the one reported by Uemura (1991). Both horizons consisted of parallel laminated mudstone. Plant macrofossils from the lower horizon (Kn-1) mostly comprised leaves and other organs such as samaras and winged seeds that were scattered parallel to the bedding plane. Plant macrofossils of the upper horizon (Kn-2) also mostly consisted of leaf remains, but they were more densely accumulated, with carbonized twigs and fruits.

In this study, all plant macrofossils reported by Narita et al. (2012) were taxonomically re-examined. We also examined specimens reported by Uemura (1991) from the same site, although we are not certain from which horizon they originated. The descriptive terminology for dicotyledonous leaves follows the protocols of Ellis et al. (2009). Terminology for the other 

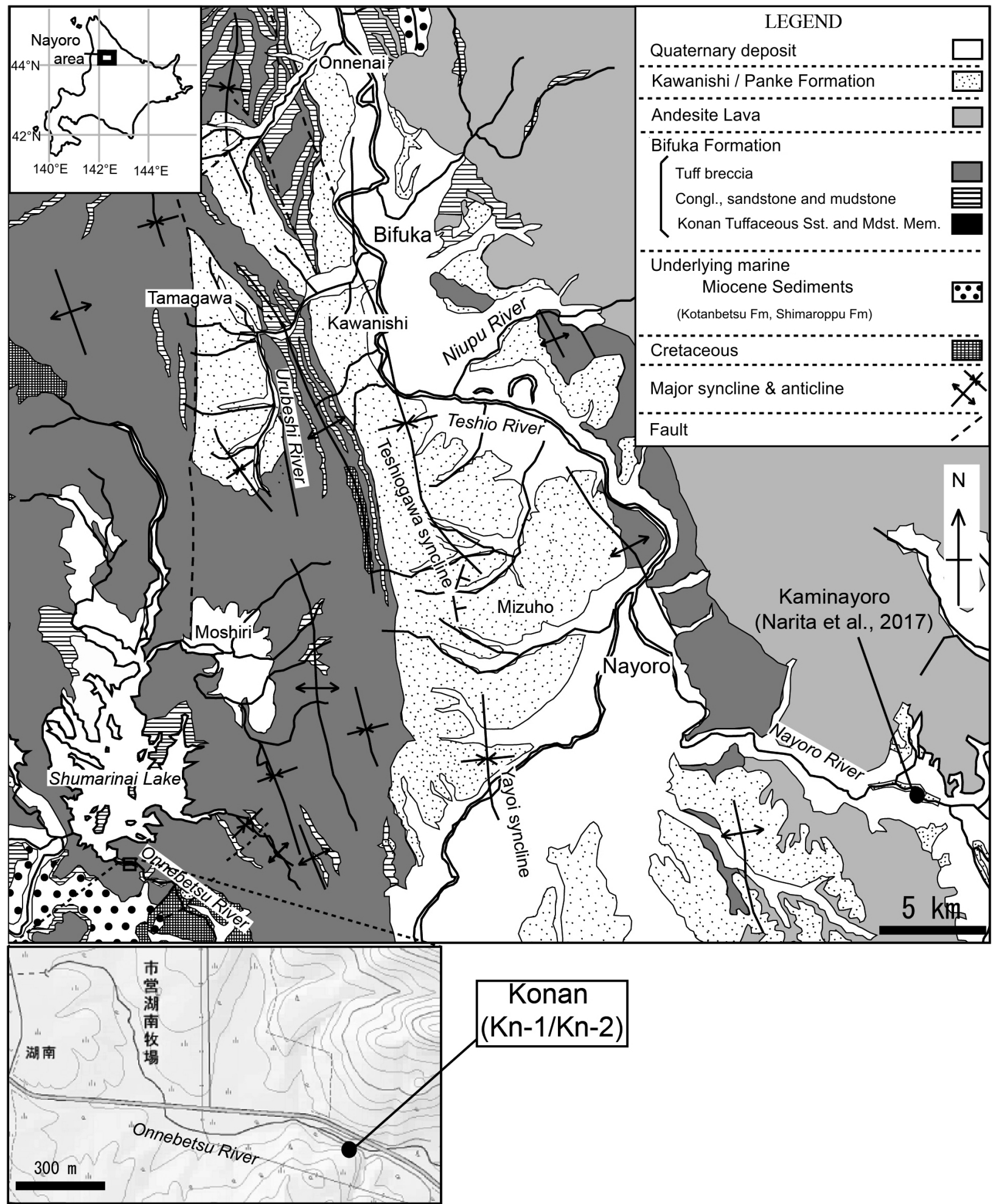

Fig. 1. Geological map and location of the Konan flora. Modified from Narita et al. (2012). Partly adapted to the 1:25000 Soeushinai topographical map of the Geospatial Information Authority of Japan

leaves or fruits is based on the relevant literature. The taxonomic arrangement of gymnosperms and angiosperms is based on Kramer and Green (1990) and APG IV (2016), respectively. The specimens used in this study are stored at the National Museum of Nature and Science, Ibaraki, Japan (NSM PP).

Most of the plant fossils are preserved as impressions, yielding no structurally preserved material. They were studied under a Nikon SMZ745T binocular microscope fitted with a Nikon DS-Fi1 digital camera. The specimens were photographed using a Pentax $\mathrm{K}$-3II digital camera with a $35 \mathrm{~mm}$ Pentax-DA macro lens at low-angle illumination.

Mean annual temperatures (MAT) of the Konan and other floras used for comparison were estimated using the following equation from Wing and Greenwood (1993): MAT $=1.141+(0.306 \times$ percentage of species with entire leaf margin). 


\section{RESULTS}

\section{FLORAL COMPOSITION}

The composition of the fossil assemblages from the two horizons was similar, with some differences that probably were due to taphonomic processes (Tabs $1 \& 2$ ). We treated this fossil flora - which consisted of 31 species from 14 families and 19 genera and included three

Table 1. Composition of the Konan flora

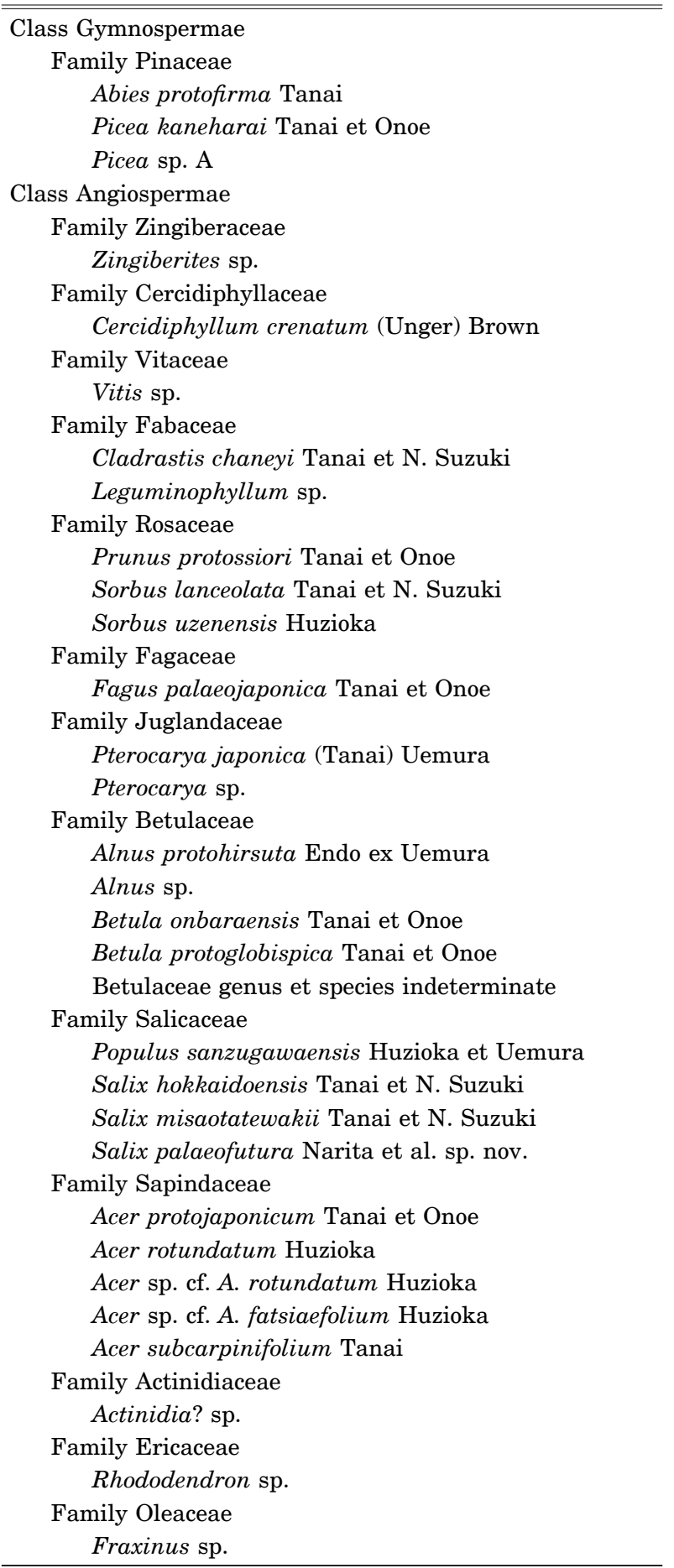

evergreen conifers, one perennial monocot herb and 27 deciduous dicots - as the Konan flora. (Tabs $1 \& 2$ ). The most abundant or common species were Fagus palaeojaponica, Acer subcarpinifolium Tanai, Acer protojaponicum Tanai \& Onoe, Picea sp. A and Cercidiphyllum crenatum (Unger) Brown; Betulaceae was the most diverse family, with 5 species. Sorbus lanceolata Tanai \& N. Suzuki, Rhododendron sp. and Fraxinus sp. were newly recognized in this study. Most genera were represented by a single or a few species. All genera that were recognized in the Konan flora, except for Zingiberites and Carpolithes, exist on the modern Japanese Islands. Most species in the assemblages were represented by leaves and leaflets (Tab. 2), while Picea sp. A, Acer protojaponicum and Acer subcarpinifolium were represented by both leaves and reproductive structures (Tab. 2).

\section{SYSTEMATIC DESCRIPTIONS}

Class: Gymnospermae

Order: Pinales

Family: Pinaceae

Genus: Abies Mill. 1754

Abies protofirma Tanai

Pl. 1, fig. 1

1961 Abies protofirma Tanai, p. 248-249, pl. 1, fig. 10. Material studied. NSM PP-12276 (Kn-2).

Stratigraphic horizon(s) and occurrence. Kn-1 and Kn-2.

Remarks. Two detached cone scales were recovered from both horizons. They are characterized by obovate shape with a smoothly round apex and short stalk. Length-to-width ratio $\sim 0.9$. Although the bract scale was not preserved in our materials, the cone scales are identical to those of Abies species, especially Abies protofirma Tanai, in their shape, length/width ratio and short stalk. Abies protofirma is most similar to the extant Abies firma Siebold \& Zucc. in general outline and scale size (Tanai, 1961). This species has been recorded in late Miocene-Pliocene floras in Honshu and Hokkaido. 
Table 2. Numerical representation of Konan flora macrofossils

\begin{tabular}{|c|c|c|c|c|c|c|c|}
\hline \multirow{2}{*}{ Taxa } & \multirow{2}{*}{ Organ } & \multicolumn{6}{|c|}{ Numerical abundance and ratio } \\
\hline & & $\mathrm{Kn}-1$ & $\%$ & $\mathrm{Kn}-2$ & $\%$ & total & $\%$ \\
\hline Abies protofirma & cs & 1 & 0.1 & 1 & 0.1 & 2 & 0.1 \\
\hline Picea kaneharai & sd & 1 & 0.1 & 1 & 0.1 & 2 & 0.1 \\
\hline \multirow[t]{2}{*}{ Picea sp. A } & lf, sh & 18 & 2.1 & 79 & 5.2 & 97 & 4.1 \\
\hline & sd & 11 & 1.3 & 66 & 4.3 & 77 & 3.2 \\
\hline Zingiberites sp. & lf & 13 & 1.5 & 1 & 0.1 & 14 & 0.6 \\
\hline Cercidiphyllum crenatum & lf & 36 & 4.2 & 47 & 3.1 & 83 & 3.5 \\
\hline Vitis sp. & lf & 7 & 0.8 & - & - & 7 & 0.3 \\
\hline Cladrastis chaneyi & lf, lft & 71 & 8.3 & 14 & 0.9 & 85 & 3.6 \\
\hline Leguminophyllum sp. & lf, lft & - & - & 3 & 0.2 & 3 & 0.1 \\
\hline Prunus protossiori & lf & 1 & 0.1 & - & - & 1 & 0.0 \\
\hline Sorbus lanceolata & lf, lft & 3 & 0.4 & - & - & 3 & 0.1 \\
\hline Sorbus uzenensis & lf, lft & 7 & 0.8 & 2 & 0.1 & 9 & 0.4 \\
\hline Fagus palaeojaponica & lf & 314 & 36.6 & 779 & 51.0 & 1093 & 45.9 \\
\hline Pterocarya japonica & lf, lft & 29 & 3.4 & 19 & 1.2 & 48 & 2.0 \\
\hline Pterocarya sp. & sd & 1 & 0.1 & 2 & 0.1 & 3 & 0.1 \\
\hline Alnus protohirsuta & lf & 45 & 5.3 & 33 & 2.2 & 78 & 3.3 \\
\hline Alnus sp. & lf & 23 & 2.7 & 24 & 1.6 & 47 & 2.0 \\
\hline Betula onbaraensis & lf & 5 & 0.6 & 9 & 0.6 & 14 & 0.6 \\
\hline Betula protoglobispica & lf & 43 & 5.0 & 34 & 2.2 & 77 & 3.2 \\
\hline Betulaceae genus et sp. indet. & sa & 3 & 0.4 & - & - & 3 & 0.1 \\
\hline Populus sanzugawaensis & lf & 28 & 3.3 & 42 & 2.8 & 70 & 2.9 \\
\hline Salix hokkaidoensis & lf & 2 & 0.2 & 2 & 0.1 & 4 & 0.2 \\
\hline Salix misaotatewakii & lf & 63 & 7.4 & 77 & 5.0 & 140 & 5.9 \\
\hline Salix palaeofutura & lf & 1 & 0.1 & 5 & 0.3 & 6 & 0.3 \\
\hline \multirow[t]{2}{*}{ Acer protojaponicum } & lf & 49 & 5.7 & 84 & 5.5 & 133 & 5.6 \\
\hline & $\mathrm{sm}$ & 1 & 0.1 & 1 & 0.1 & 2 & 0.1 \\
\hline Acer rotundatum & lf & 16 & 1.9 & 36 & 2.4 & 52 & 2.2 \\
\hline Acer sp. cf. A. rotundatum & sm & 1 & 0.1 & - & - & 1 & 0.0 \\
\hline Acer sp. cf. A. fatsiaefolium & lf & 5 & 0.6 & 4 & 0.3 & 9 & 0.4 \\
\hline \multirow[t]{2}{*}{ Acer subcarpinifolium } & lf & 53 & 6.2 & 155 & 10.2 & 208 & 8.7 \\
\hline & $\mathrm{sm}$ & 3 & 0.4 & 4 & 0.3 & 7 & 0.3 \\
\hline Actinidia? sp. & lf & 1 & 0.1 & - & - & 1 & 0.0 \\
\hline Rhododendron sp. & lf & 1 & 0.1 & - & - & 1 & 0.0 \\
\hline Fraxinus sp. & lft & 1 & 0.1 & 1 & 0.1 & 2 & 0.1 \\
\hline Total & - & 857 & 100 & 1525 & 100 & 2382 & 100 \\
\hline
\end{tabular}

cs - cone scale, lf - leaf, lft - leaflet, sa - staminate ament, sd - seed, sh - shoot, sm - samara

Genus: Picea A. Dietr., 1824

\section{Picea kaneharai Tanai \& Onoe}

Pl. 1, fig. 2

1961 Picea kaneharai Tanai \& Onoe, p. 17, pl. 1, fig. 9.

1973 Picea kaneharai Tanai \& Onoe; Huzioka and Uemura, p. 698, pl. 1, figs 14-20.

Material studied. NSM PP-12277 (Kn-2).

Stratigraphic horizon(s) and occurrence. Kn-1 and Kn-2.

Remarks. Several winged seeds were obtained from both horizons. They are identical to Picea kaneharai Tanai \& Onoe in the shape and size of the spatulate wing. This species resembles the modern Picea polita Carrière, which grows in the mountains of central to southern Honshu at $\sim 1,000 \mathrm{~m}$ above sea level. This species has been reported from early to late Miocene floras (e.g. Miyata flora: Huzioka and Uemura, 1973) around the Sea of Japan area.

\section{Picea sp. A}

Pl. 1, figs 3-6

2012 Picea sp. Narita et al., figs 4-5, 6.

2017 Picea sp. Narita et al., figs 5-3, 4.

Materials studied. NSM PP-12198, seed (Kn-2); 12197, 12278, shoot (Kn-2).

Stratigraphic horizon(s) and occurrence. Kn-1 and Kn-2.

Rem arks. A number of isolated spruce seeds, shoots and leaves were obtained from both 
horizons. These leaves and shoots are clearly identical to those of the genus Picea, with very narrow, sessile leaf blades and convex to acuminate apexes. The winged seeds are also identical to those of the genus, with oblong to triangular wings and bluntly pointed seed bases (e.g. modern Picea jezoensis Carrière). Each organ is remarkably similar to what has been found in the Kaminayoro flora (Narita et al., 2017). In the Kaminayoro localities, isolated spruce organs were found to have accumulated in certain bedding planes of the flood plain and abandoned channel deposits; thus we regard them as a single species. This species probably was a common element of the riparian vegetation during the middle to late Miocene.

Class: Angiospermae

Order: Zingiberales

Family: Zingiberaceae

Genus: Zingiberites Heer, 1859

\section{Zingiberites sp.}

Pl. 1, figs 7-12

2012 Zingiberites sp. Narita et al., fig. 5-2.

Materials studied. NSM PP-12210, 12279 (Kn-1).

Stratigraphic horizon(s) and occurrence. Kn-1 and Kn-2.

Description. Laminae slightly asymmetrical, length $\geq 12 \mathrm{~cm}$ (probably $>13 \mathrm{~cm}$ ), width 6-10 cm; apex not preserved, base acute, narrowly attenuate; petiole not preserved; margin entire, without marginal vein; venation parallelodromous; medial vein or costa straight, 3.1-3.6 mm wide near base, abruptly tapering upward, becoming indistinct apically; lateral veins eucamptodromous, parallel, thickness showing at least three different orders, decurrent at divergence, gently curved, angle from midvein measured $10 \mathrm{~mm}$ apart $\sim 20-30^{\circ}$; penultimate lateral veins (2nd-order) distanced 4-5/mm; ultimate laterals (3rd-order) very thin, indistinct, three veins between penultimate lateral veins; transverse veins as thick as penultimate lateral veins, irregularly percurrent, closely spaced $(5-7 / \mathrm{mm})$, nearly perpendicular to lateral vein, forming irregular meshes; cuticle not preserved.
Re marks. Some leaf fragments in the Konan flora show large leaves with parallelodromous venation and a thick medial vein consisting of a set of primary veins (costa), which is relatively narrow $(\sim 3 \mathrm{~mm})$. The lateral veins are composed of three-ordered parallel veins that diverge at a narrowly acute angle from the costa. The parallel veins are connected by closely spaced transverse veins that are nearly perpendicular to the parallel veins. These features are typical of leaves of members of the ginger family (Zingiberaceae). Fossil leaves of this family have been named under several different fossil genera, such as Zingiberites Heer, Zingiberoideophyllum Kräusel \& Weyland and Zingiberopsis Hickey $\&$ Pederson, although they may not have been well differentiated (Kunzmann, 2012). Among these genera, our specimens yielded more closely arranged transverse veins than those of Zingiberopsis (Hickey and Pederson, 1978) or Zingiberoideophyllum (Kunzmann, 2012). Details of venation are not well understood in Zingiberites because of the loss of type materials; however, we tentatively designated our materials as Zingiberites sp., which have been recorded from the Miocene of Europe (Heer, 1859, 1869) and Greenland (Saporta, 1888). No fossil leaf similar to this species has previously been reported from Japan.

\section{Order: Saxifragales}

Family: Cercidiphyllaceae

Genus: Cercidiphyllum Siebold \& Zucc, 1846

Cercidiphyllum crenatum (Unger) Brown

Pl. 3, figs 1-4

1850 Dombeyopsis crenata Unger, p. 448.

1935 Cercidiphyllum crenatum (Unger) Brown, p. 575, pl. 68, figs 1-11; pl I, fig. 8.

1991 Cercidiphyllum crenatum (Unger) Brown; Uemura, p. 20, pl. 2, figs 2-6, 8 .

2017 Cercidiphyllum crenatum (Unger) Brown; Narita et al., p. 137, fig. 5-6.

Materials studied. NSM PP-12205, 12280 (Kn-1).

Stratigraphic horizon(s) and occurrence. Kn-1 and Kn-2.

Remarks. Many leaves having an orbiculate shape, cordate base, shortly acuminate 


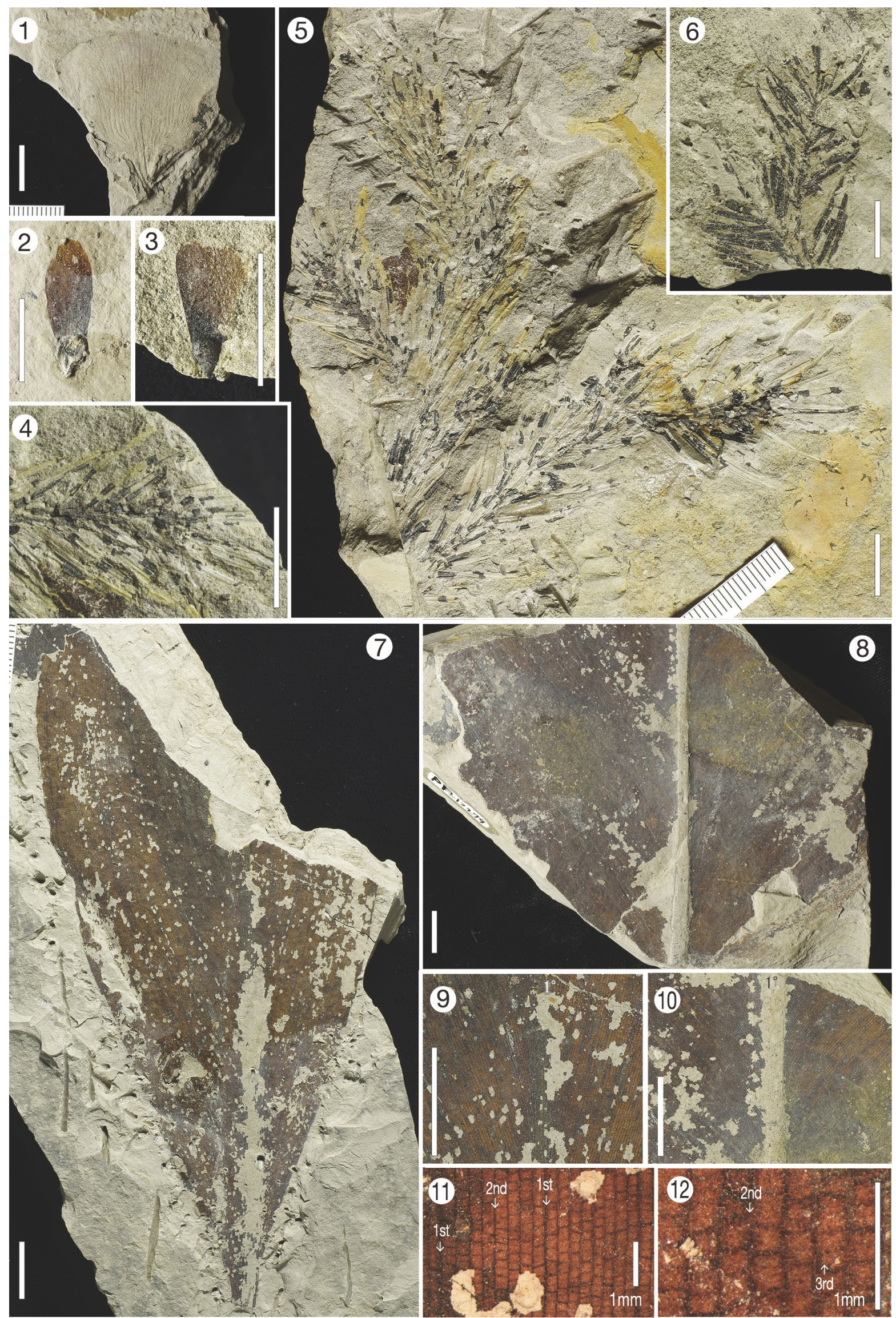

Plate 1. 1. Abies protofirma Tanai, cone scale, NSM PP-12276, Kn-2; 2. Picea kaneharai Tanai \& Onoe, winged seed, NSM PP-12277, Kn-2; 3-6. Picea sp. A; 3. winged seed, NSM PP-12198, Kn-2; 4, 5. shoot, NSM PP-12197, Kn-2; 6. shoot, NSM PP-12278, Kn-2; 7-12. Zingiberites sp.; 7, 9, 11, 12. leaf, NSM PP-12279, Kn-1; 8, 10. leaf, NSM PP-12210, Kn-1. $1^{\circ}$ : primary vein. 1st, 2nd, 3rd: first-, second- and third-order lateral veins. Scale bars $=1 \mathrm{~cm}$ unless otherwise noted 
apex, crenate margin, basal actinodromous and festooned brochidodromous venation were obtained from both horizons. They are clearly identical to Cercidiphyllum crenatum (Unger) Brown in overall characters (sensu Brown, 1935). This is one of the common species in late middle-late Miocene floras of Hokkaido (e.g. Uemura, 1991; Narita et al., 2017).

\section{Order: Vitales}

Family: Vitaceae

Genus: Vitis L., 1953

\section{Vitis sp.}

Pl. 2, figs 7-12

Materials studied. NSM PP-12281, 12282 (Kn-1).

Stratigraphic horizon(s) and occurrence. Kn-1.

Description. Lamina three-lobed palmate, with shallow sinuses; medial lobe triangular, with approximately the same width as lateral lobes at its base; primary vein of lateral lobe approximately the same length as medial vein; lobe sinuses angular, wide obtuse; laminae symmetrical, variable in size, length $7-15 \mathrm{~cm}$, width $7-17 \mathrm{~cm}, \mathrm{~L}: \mathrm{W}$ ratio $1.0-1.1$, pentagonal in shape; lateral lobe apex acute, long acuminate; base angle reflexed, deeply cordate, with straight to convex sides; petiole stout, $\geq 5 \mathrm{~cm}$ long; margins serrate; teeth simple, rarely compound, distantly arranged; distal flank of teeth convex to retroflexed, proximal flank nearly straight, tooth apices wide-acute to obtuse with a blunt tip; principal vein enters tooth slightly basally; sinuses between two primary teeth typically round; sinuses between subsidiary teeth rarely angular; venation palmate and basally actinodromous; three primary veins thin; medial primary straight or sinuous, gradually tapering toward apex; lateral primaries gently curved, recurved admedially; secondary veins thin, semicraspedodromous, $\geq 3$ subopposite pairs diverge from primary vein at $\sim 45^{\circ}$, upward curving, abruptly curving up near margin, sending off tertiary veins to the tooth; secondary veins parallel, vein spacing increases proximally; basal pair of secondaries form simple agrophic veins; intercostal tertiary veins irregular reticulate; tertiary and quaternary veins form large polygonal meshes; areoles well developed, diameter $<1 \mathrm{~mm}$; freely ending veinlets absent, rarely present, branching once or more.

Remarks. The two fragmentary specimens possess a pentagonal foliar shape, deeply cordate base, and basal actinodromous secondary venation. The margins of these specimens are simple serrate in which minor secondaries entered medially. All of these features are comparable to those of the genus Vitis. More complete materials are needed to make an assignment at species level.

\section{Order: Fabales}

Family: Fabaceae

Genus: Cladrastis Raf., 1824

\section{Cladrastis chaneyi Tanai \& N. Suzuki}

$$
\text { Pl. 2, figs 1-6 }
$$

1965 Cladrastis chaneyi Tanai \& N. Suzuki, p. 33, pl. 10, fig. 1; pl. 21, fig. 1.

1988 Cladrastis chaneyi Tanai \& N. Suzuki; Uemura, p. 147-148, pl. 9, figs 11-14.

Materials studied. NSM PP-12206, 12283 (Kn-1).

Stratigraphic horizon(s) and occurrence. Kn-1 and Kn-2.

Remarks. A number of legume leaflets were recognized in the Konan flora. They are identical to Cladrastis chaneyi, with a short acuminate apex, closely spaced brochidodromous secondaries, percurrent intercostal tertiaries, and moderately developed areoles with branched veinlets. Since its original description from the Shanabuchi (late Miocene) and Rubeshibe (Pliocene) floras of northern Hokkaido (Tanai and Suzuki, 1965), this species has been recorded among other Miocene and Pliocene floras in Japan (Uemura, 1988). Tanai \& N. Suzuki (1965) compared it with the extant Cladrastis kentukea (Dum.Cours.) Rudd (= Cladrastis lutea) growing in North America. In overall shape and in having closely arranged, smoothly curved, parallel secondaries, Cladrastis chaneyi is also similar to Cladrastis platycarpa (Maxim.) Makino, which grows in temperate forests of Honshu 


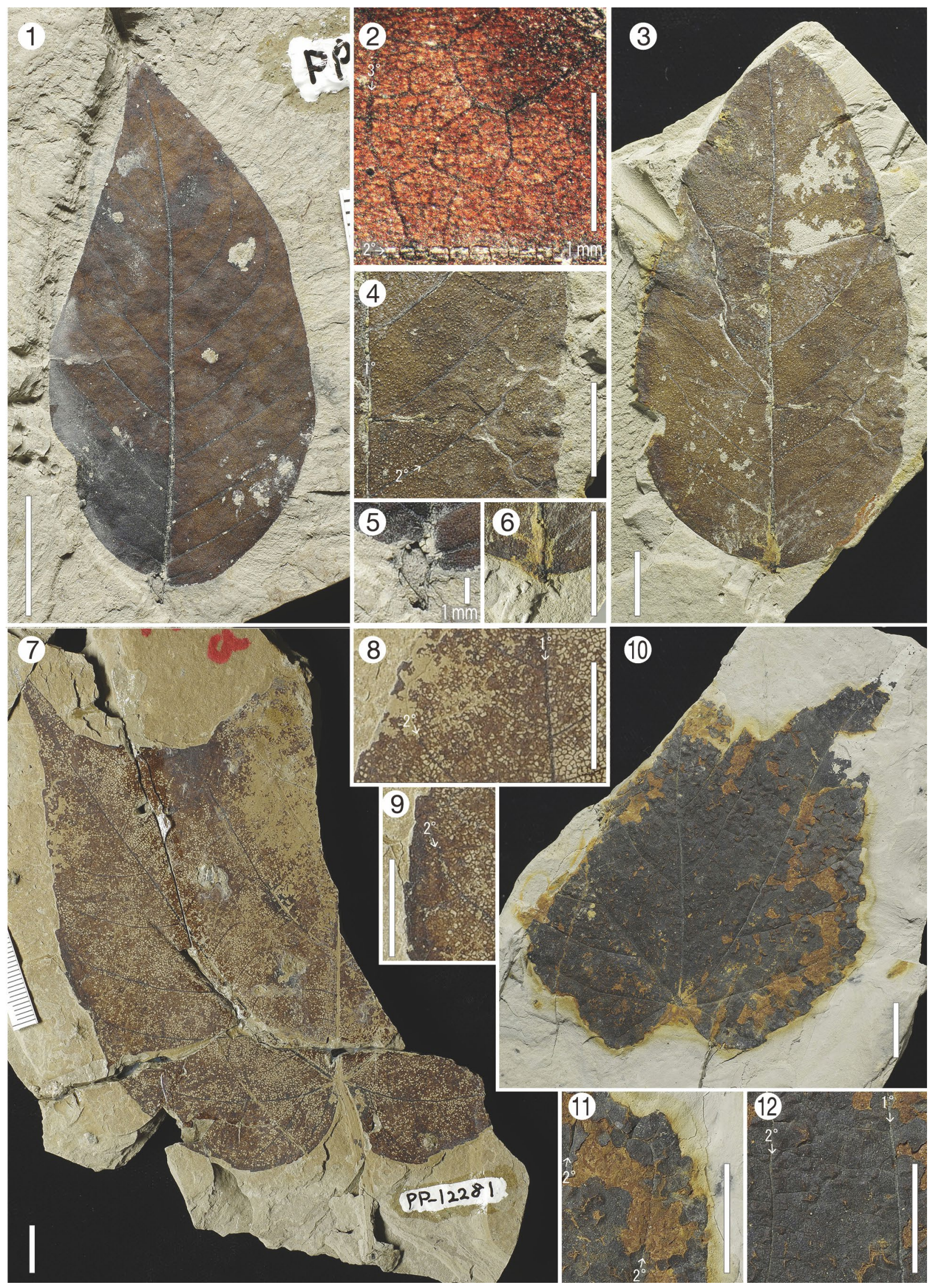

Plate 2. 1-6. Cladrastis chaneyi Tanai \& N. Suzuki; 1, 2, 5. leaflet, NSM PP-12283, Kn-1; 3, 4, 6. leaflet, NSM PP-12206, Kn-1; 7-12. Vitis sp.; 7-9. leaf, NSM PP-12281, Kn-1; 10-12. leaf, NSM PP-12282, Kn-1. $1^{\circ}, 2^{\circ} \& 3^{\circ}$ : primary, secondary and tertiary veins. Scale bars $=1 \mathrm{~cm}$ unless otherwise noted 
and Shikoku in Japan and in central China. Cladrastis chaneyi is also common in lacustrine deposits of the Kaminayoro flora (Narita et al., 2017). Therefore, Cladrastis chaneyi is assumed to have inhabited lakesides in this region.

Genus: Leguminophyllum

Escalup-Bassi, 1971

\section{Leguminophyllum sp.}

Pl. 3, figs 5-8

Material studied. NSM PP-12317 (Kn-2).

Stratigraphic horizon(s) and occurrence. Kn-2.

Description. Leaves odd-pinnately compound, terminal leaflet not well preserved, lateral leaflet opposite; leaflet laminae basally asymmetrical, length $3.5-7 \mathrm{~cm}$, width $1.4-3 \mathrm{~cm}, \mathrm{~L}: \mathrm{W}$ ratio $2-2.5$, elliptic to oblong shape; apex acute, straight or slightly convex with round apex, base obtuse, round; petiolule short, $\sim 2 \mathrm{~mm}$, pulvinus; margin entire; venation pinnate; primary vein stout, straight, gradually tapering toward apex; secondary vein eucamptodromous, thick and distinct near primary, abruptly tapers distally, $\geq 7$ pairs, opposite to subopposite, irregularly spaced, diverging from primary at $\sim 45^{\circ}$ on middle portion, but acuter angle proximally, straight then curving upward to form a series of loops; intersecondary veins usually present, short, diverging at higher angle than contiguous secondaries; tertiary veins indistinct, diverging from secondaries at $60-110^{\circ}$, opposite percurrent or irregularly reticulate; quaternary veins thick, alternate percurrent, forming orthogonal meshes; areoles apparently well developed; veinlets branched once or more.

Remarks. This pinnately compound leaf can be assigned to the Fabaceae based on the following features: (1) elliptic to oblong, entiremargined leaflets with round apices and bases; (2) pulvinus petiolule; and (3) eucamptodromous secondary venation. Among the genera of the legume family, the specimen was somewhat similar to Maackia with a round apex and remotely arranged, thick secondary veins that are straight and rise at a wide acute angle and abruptly curved upward and tapered toward the margin. However, our specimen was not preserved well enough to observe the fine-venation characteristics in detail. Therefore we compared it to members of the genus Leguminophyllum, an organ genus applicable to isolated legume leaflets.

Order: Rosales

Family: Rosaceae

Genus: Prunus L., 1754

Prunus protossiori Tanai \& Onoe

Pl. 4, figs 1-3

1955 Prunus ssiori (F.Schmidt) C.K.Schneid.; Okutsu, p. 100, pl. 4, fig. 2.

1961 Prunus protossiori Tanai \& Onoe, p. 44, pl. 13, figs 6,7 .

Material studied. NSM PP-12284 (Kn-1).

Stratigraphic horizon(s) and occurrence. Kn-1.

Remarks. Our materials are clearly identical to those of the genus Prunus complex in the simple leaves with semicraspedoromous secondary venation, arrangement of intercostal tertiaries, and typical spinose tooth. They also have small, equal-sized teeth similar to those of Prunus protossiori Tanai \& Onoe, which was originally described from the late Miocene Onbara flora of western Japan (Tanai and Onoe, 1961).

The overall features of Prunus protossiori are similar to those of extant Prunus ssiori, which is distributed across northern Honshu, Hokkaido, Sakhalin, the Kuril Islands, northeast China, and Ussuri. Prunus protossiori has been recorded in late Miocene floras from Japan and probably is one of the common species of the Mitoku-type flora.

Genus: Sorbus L., 1753

\section{Sorbus lanceolata Tanai \& N. Suzuki}

Pl. 4, figs 9-11

1965 Sorbus lanceolata Tanai \& N. Suzuki, p. 32, pl. 13 , fig. 3 .

Material studied. NSM PP-12286 (Kn-1).

Stratigraphic horizon(s) and occurrence. Kn-1 and Kn-2. 


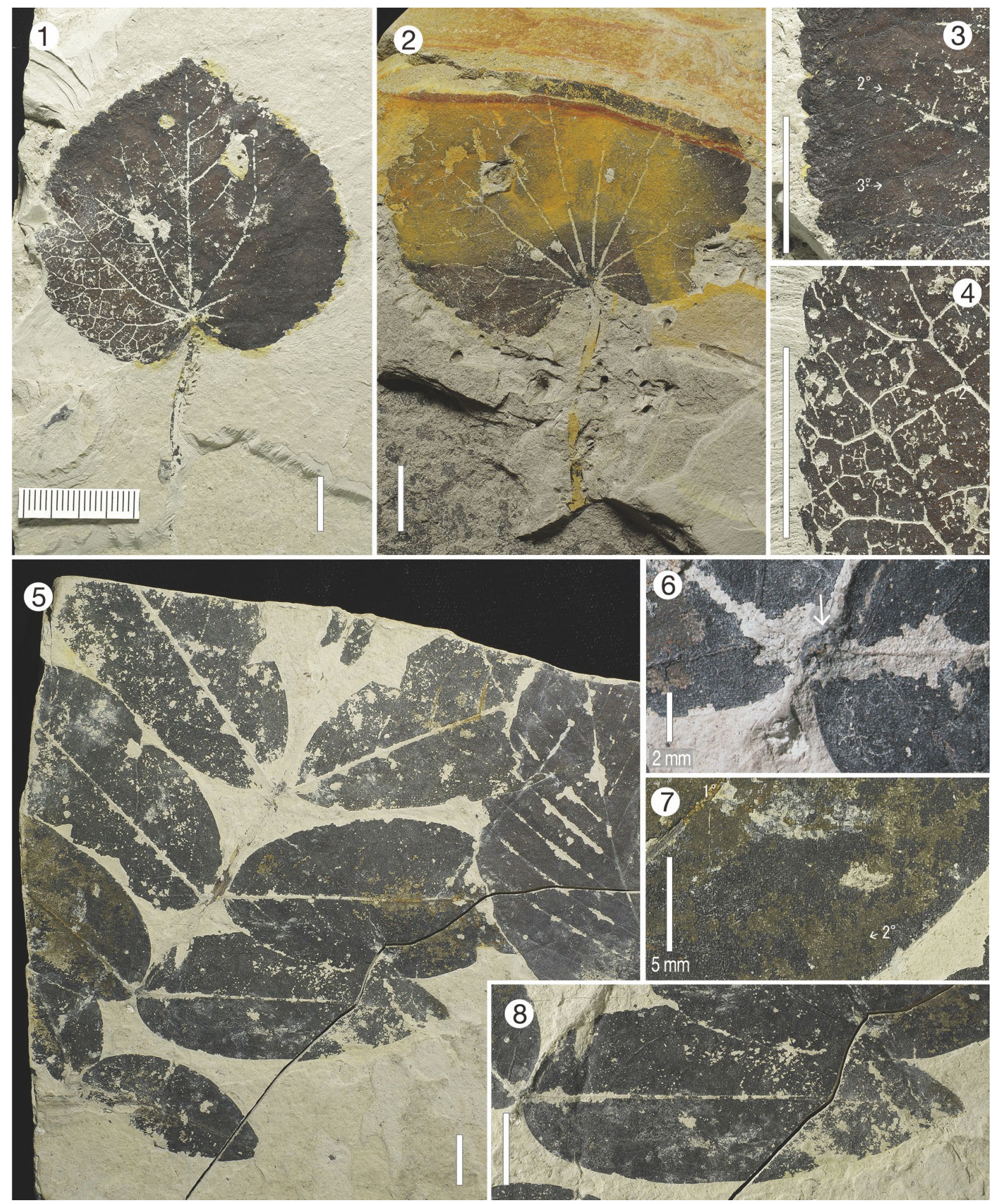

Plate 3. 1-4. Cercidiphyllum crenatum (Unger) Brown; 1, 3, 4. leaf, NSM PP-12205, Kn-1; 2. leaf, NSM PP-12280, Kn-1; 5-8. Leguminophyllum sp., leaf, NSM PP-12317, Kn-2. Arrow in figure 6 points to pulvinus. $1^{\circ}, 2^{\circ} \& 3^{\circ}$ : primary, secondary and tertiary veins. Scale bars $=1 \mathrm{~cm}$ unless otherwise noted

Description. Leaves pinnately compound, terminal leaflet not preserved, lateral leaflets oppositely arranged; leaflet laminae basally asymmetrical, length $4-7 \mathrm{~cm}$, width $1.5-2 \mathrm{~cm}$, $\mathrm{L}: \mathrm{W}$ ratio $2.7-5$, narrow oblong in shape; apex acute, straight, base acute, convex; petiolule short; margin entire in lower half, serrate in upper half of blade; teeth simple, distant, evenly spaced, at intervals of $<2 \mathrm{~mm}$; proximal side of teeth straight or weakly flexuous, distal side convex or flexuous, tooth apex acutely pointed; principal vein enters teeth slightly basally; sinuses angular, narrowly acute; venation pinnate; primary vein stout, straight, gradually tapering toward apex; secondary veins craspedodromous, thick, opposite, slightly sinuous, $\geq 9$ pairs, regularly spaced, diverging from primary at $\sim 50^{\circ}$ on middle portion, straight, 


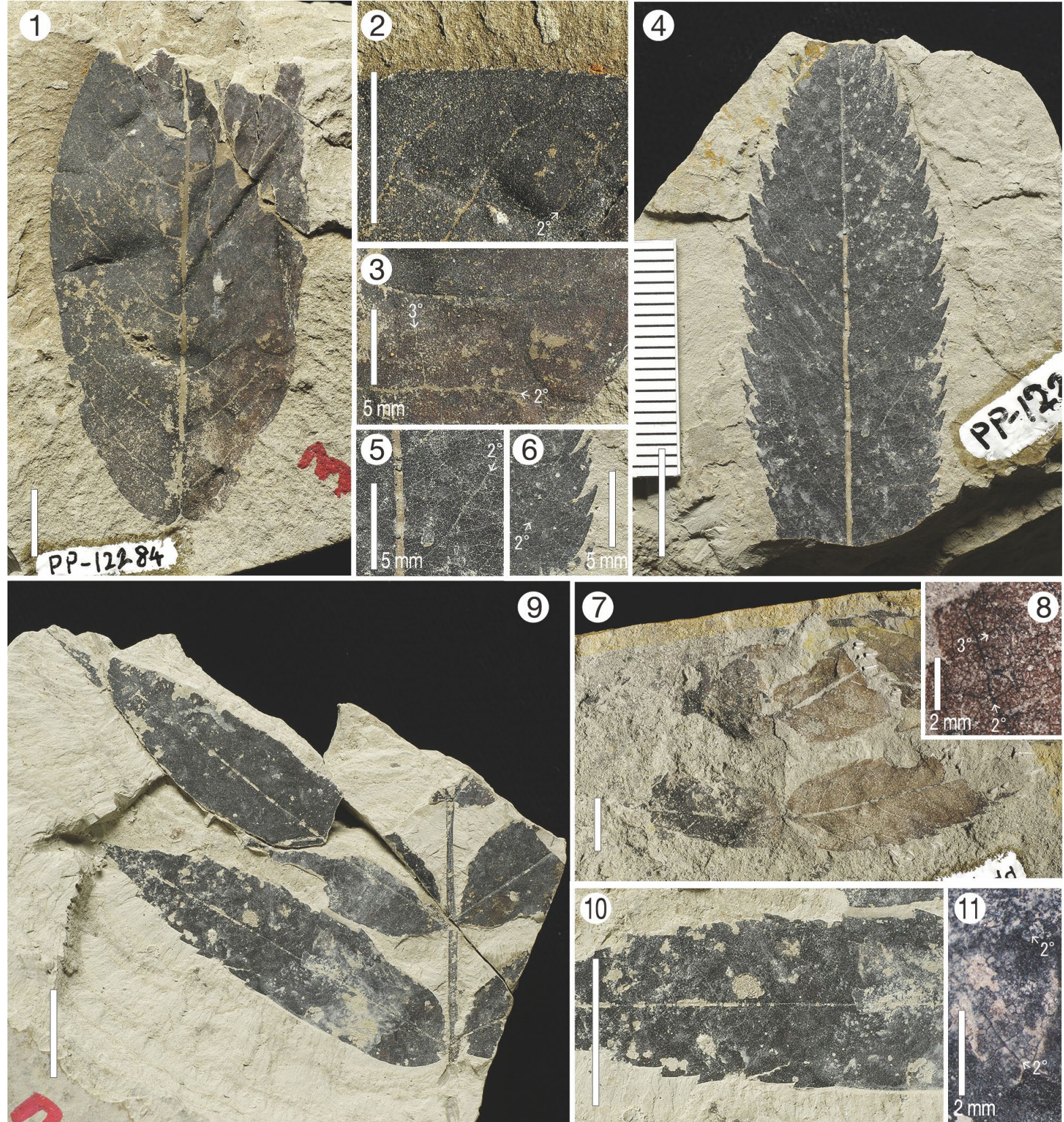

Plate 4. 1-3. Prunus protossiori Tanai \& Onoe, leaf, NSM PP-12284, Kn-1; 4-8. Sorbus uzenensis Huzioka; 4-6. leaflet, NSM PP-12285, Kn-1; 7, 8. leaf, NSM PP-12287, Kn-2; 9-11. Sorbus lanceolata Tanai \& N. Suzuki, leaf, NSM PP-12286, Kn-1. $2^{\circ}$ $\& 3^{\circ}:$ secondary and tertiary veins. Scale bars $=1 \mathrm{~cm}$ unless otherwise noted

curving upward near margin; tertiary veins medium, opposite percurrent, obtuse to midvein, angle decreasing exmedially; quaternaries random reticulate, forming irregular polygonal meshes; veinlets branched once to several times.

Remarks. Several leaves and leaflets that were newly recognized in the Konan flora were assigned to Sorbus lanceolata based on their narrow oblong shape, margin characteristics, entire lower half and serrate upper half. Tanai \& N. Suzuki (1965) maintained that this species was related to extant Sorbus matsumurana
(Makino) Koehne, which grows on the high mountains of Hokkaido and northern and central mountains in Honshu in Japan.

\section{Sorbus uzenensis Huzioka}

$$
\text { Pl. 4, figs 4-8 }
$$

1964 Sorbus uzenensis Huzioka, p. 86, pl. 8, figs 8, $8 \mathrm{a}, 9$.

Materials studied. NSM PP-12285 (Kn-1) and 12287 (Kn-2).

Stratigraphic horizon(s) and occurrence. Kn-1 and Kn-2. 
Description. Leaves pinnately compound, terminal leaflet not preserved, lateral leaflet oppositely arranged; leaflet laminae basally asymmetrical, length $5-9 \mathrm{~cm}$, width $2-3 \mathrm{~cm}$, $\mathrm{L}: \mathrm{W}$ ratio $2-3$, elliptic to oblong in shape; apex probably acute, straight, base acute, convex; petiolule short; margin doubly serrate on upper three-fourths of blade, entire basally; marginal teeth compound, normally one subsidiary tooth situated on proximal side of principal tooth, secondary vein enters each tooth slightly apically; proximal flank of tooth convex, distal flank concave or flexuous, forming acutely pointed tip; sinus angular, acute; venation pinnate; primary vein stout, straight, gradually tapering toward apex; secondary veins craspedodromous, thick, opposite to subopposite, $\geq 11$ pairs, regularly spaced, diverging from primary at $\sim 60^{\circ}$ on middle portion, gently curved, forked several times toward margin; intersecondaries present, normally 1-2, short, parallel to contiguous secondaries; tertiary veins medium, random reticulate, rarely percurrent, obtuse to midvein at uniform angle; quaternary veins irregularly reticulate, forming polygonal areoles of irregular size; veinlet probably branched several times.

Remarks. Several leaves and leaflets were recognized in the Konan flora. They are identical to Sorbus uzenensis Huzioka, which was originally described from the early Miocene Nishitagawa (Tanai, 1952), Seki (Huzioka and Nishida, 1960) and Aniai (Huzioka, 1964) floras by its doubly serrate margin and forked secondaries that end in marginal teeth apically. The late Miocene occurrence of this species was recorded for the first time by Tanai \& N. Suzuki (1965) from the Shanabuchi flora of northern Hokkaido and subsequently by several authors from northern to central Japan. It became apparent that this species was more common among the late Miocene and Pliocene floras in Japan. This species can be distinguished from Sorbus lanceolata due to its slightly wider leaflet laminae, compound marginal teeth, greater number of secondaries, and the presence of marginal teeth on the basal halves of the blades. This species resembles Sorbus commixta Hedl and Sorbaria sorbifolia (L.) A. Braun var. stellipila Maxim. (Narita et al., 2012); however, the current species is distinct from those two taxa due to its weakly curved secondary veins and the concave shape of the distal flank of the marginal teeth.

\section{Order: Fagales}

Family: Fagaceae

Genus: Fagus L., 1753

\section{Fagus palaeojaponica Tanai \& Onoe}

\author{
Pl. 5, figs 1-6
}

1883 Fagus sieboldii Endl., Nathorst, p. 84, pl. 15, fig. 6.

1888 Fagus japonica Maxim., Nathorst, p. 227, pl. 9, figs 3-8.

1959 Fagus protojaponica Suzuki, p. 33, pl. 2, fig. 10.

1961 Fagus palaeojaponica Tanai \& Onoe, p. 35, pl. 7, figs 3-5.

Materials studied. NSM PP-10456, 10457, 10458, 10459, 10460, 10461, 10462, 10463a, 10463b, 10466 (horizon uncertain); NSM PP-12204, 12289, 12290 (Kn-1) and NSM PP-12322, 12323 (Kn-2).

Stratigraphic horizon(s) and occurrence. Kn-1 and Kn-2.

Description. Laminae symmetrical or slightly asymmetrical, length 7-18 cm, width $3.5-11 \mathrm{~cm}, \mathrm{~L}: \mathrm{W}$ ratio $1.6-2.0$, elliptic or slightly obovate in shape; apex acute, acuminate: base acute to obtuse, round; petiole, stout, short, $<1 \mathrm{~cm}$ long; margin entire, at times slightly undulate, rarely sinuous along upper blade; venation pinnate; primary vein stout, straight; secondary veins thick, $\geq 15$ pairs, opposite, sometimes subopposite, parallel, regularly spaced, diverging from primary at $\sim 45-60^{\circ}$ on middle portion, eucamptodromous; intercostal tertiaries percurrent, straight, regularly spaced, perpendicular to adjacent secondaries; quaternary and quintenary veins irregular reticulate, forming oblong to polygonal areoles of irregular size; veinlet irregular in ramification, branching once to several times, with gradually thinning tips.

Remarks. Abundant leaves were recognized among the Konan flora. According to their marginal characteristics and regularly spaced secondary and tertiary veins, these specimens are clearly identical to Fagus palaeojaponica (Nathorst) Tanai \& Onoe. The leaves of this species resemble those of the extant Fagus japonica Maxim., which grows on the Pacific side of the Honshu and Kyushu Islands, and to those of Fagus multinervis Nakai on Ulleungdo Island, Korea, in both the general shape and number of secondaries. However, some 


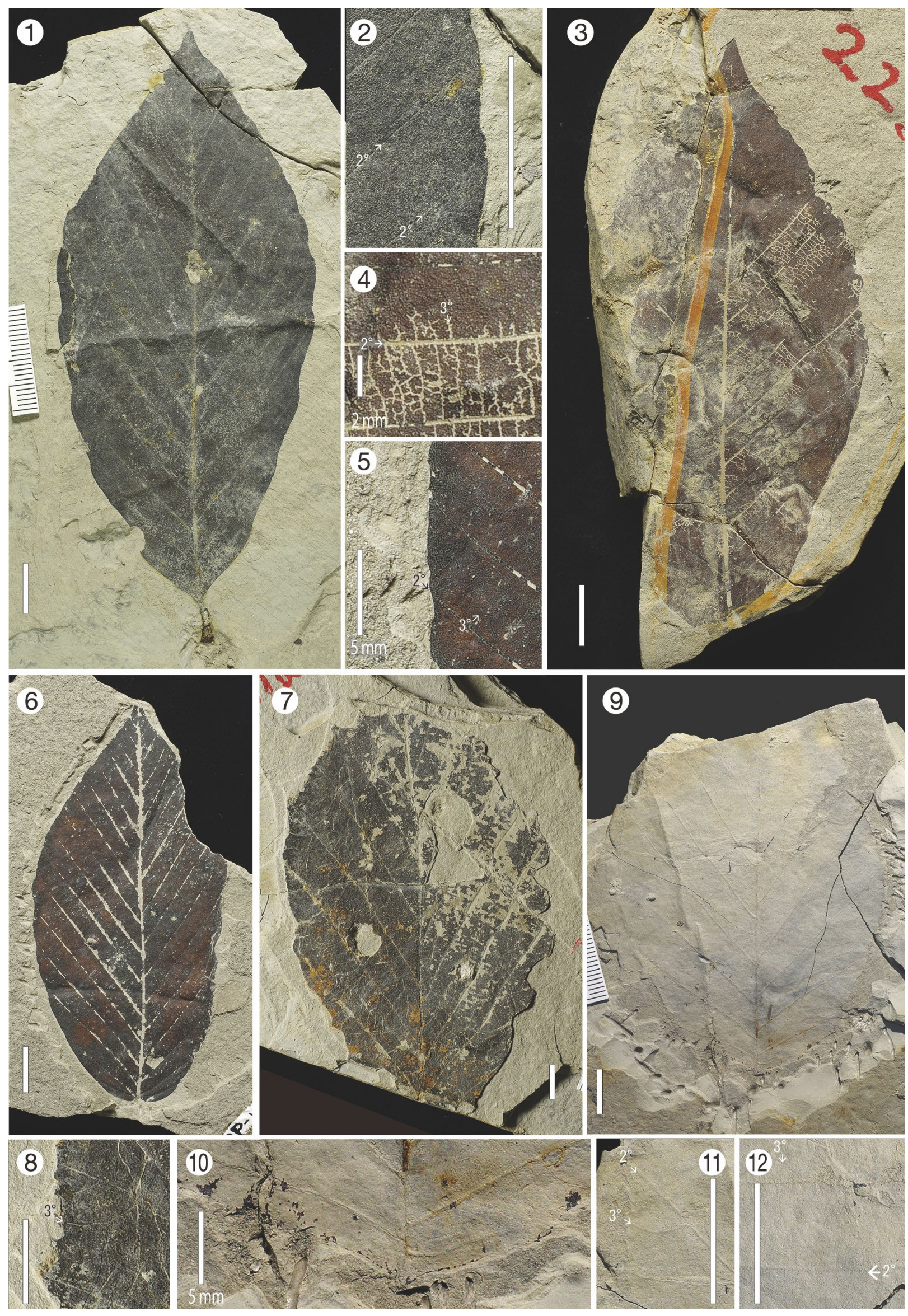

Plate 5. 1-6. Fagus palaeojaponica Tanai \& Onoe; 1, 2. leaf, NSM PP-12204, Kn-1; 3, 4. leaf, NSM PP-12289, Kn-1; 5, 6. leaf, NSM PP-12290, Kn-1; 7-12. Alnus sp.; 7, 8. leaf, NSM PP-12294a, Kn-1; 9-12. leaf, NSM PP-12294b, Kn-1. $2^{\circ}$ \& $3^{\circ}$ : secondary and tertiary veins. Scale bars $=1 \mathrm{~cm}$ unless otherwise noted 
incomplete cupules co-occurring in the Konan Tuffaceous Sandstone and Mudstone Member of the Bifuka Formation are distinct from those of modern species due to their much larger size and relatively long spiny appendages on the surface. Therefore, its relationship to modern species should be evaluated in future studies.

Fagus palaeojaponica dominated the lacustrine deposits of the Konan Tuffaceous Sandstone and Mudstone Member of the Bifuka Formation. This species was known to dominate in montane vegetation of the Kaminayoro flora (Narita et al., 2017). Similar trends have been recognized among the late Miocene Shanabuchi and Pliocene Rubeshibe floras of northern Hokkaido. Therefore, Fagus palaeojaponica beech forest was well developed in northern Japan during the late middle Miocene to Pliocene, which contrasts with the beech forest dominated by Fagus stuxbergi in southern Japan (Uemura, 1991).

Family: Juglandaceae

Genus: Pterocarya Kunth, 1824

\section{Pterocarya japonica (Tanai) Uemura}

Pl. 6, figs $1,2,4,5$

1961 Juglans japonica Tanai, p. 275, pl. 6, figs 9, 10.

1988 Pterocarya japonica Uemura, p. 132, pl. 8, fig. 1 (see for synonymy).

2012 Pterocarya japonica Uemura; Narita et al., figs $4-7,8$.

Materials studied. NSM PP-12291 (Kn1), 12200 (Kn-2), 12469 (horizon unknown).

Stratigraphic horizon(s) and occurrence. Kn-1 and Kn-2.

Remarks. Some Pterocarya leaves and leaflets have been recovered from the Konan Tuffaceous Sandstone and Mudstone Member of the Bifuka Formation. Identifying juglandaceous leaves among the Miocene floras of Japan has been challenging. The current species was originally described as a new species of Juglans based on leaflet remains from the Upper Miocene Shanabuchi Formation (Tanai, 1961), which showed regularly spaced small triangular teeth and a single series of secondary loops (semicraspedodromous). Based on these characters, Uemura (1988) transferred it to Pterocarya. The species is also characterized by its oblong to elliptic shape and relatively closely spaced secondary veins, and is distinct from Pterocarya protostenoptera Tanai of the early to late Miocene floras of Japan.

This species has been compared with an extant endemic species of Japan, Pterocarya rhoifolia Siebold \& Zucc., in its short acuminate apex and its sharply pointed triangular teeth distributed evenly over the margin. Narita et al. (2017) revealed that Pterocarya japonica was one of the constituents of riparian vegetation in the Kaminayoro flora (Narita et al., 2017), based on its occurrence and the depositional features of associated sediments. This species is also common among the Neogene floras of Japan.

\section{Pterocarya sp.}

Pl. 6, fig. 3

Materials studied. NSM PP-12201(Kn-2).

Stratigraphic horizon(s) and occurrence. Kn-1 and Kn-2.

Description. Obliquely compressed fruit, winged, stigma not preserved; nut probably two-valved, deep striations on surface, $\geq 7 \mathrm{~mm}$ long, $5.5 \mathrm{~mm}$ wide; nut-enclosed area $10.5 \times$ $9.3 \mathrm{~mm}$ on surface; wing reniform, $\geq 16.6 \mathrm{~mm}$ long from center, $\geq 16.3 \mathrm{~mm}$ wide; veins radiating, relatively evenly spaced, bifurcated several times toward margin, tapering exmedially.

Remarks. Three incomplete, isolated winged nuts were recovered from $\mathrm{Kn}-1$ and $\mathrm{Kn}-2$. These specimens are identical to Pterocarya based on wing shape. They are closest to the modern Pterocarya rhoifolia Siebold \& Zucc. in all morphological characters. This is the first report of winged nuts similar to the extant Pterocarya rhoifolia in Miocene or earlier floras in Japan. They were found in the same horizon with Pterocarya japonica; it is highly probable that the nuts belong to the same species, but we hesitate to make that assignment because we did not find botanical connections between the two organs.

\section{Family: Betulaceae}

Genus: Alnus Mill., 1754

\section{Alnus protohirsuta Endo ex Uemura}

\author{
Pl. 7, figs 1-4
}

1940 Alnus hirsuta Okutsu, p. 157, pl. 9, figs 3, 4. 1955 Alnus protohirsuta Endo (nom. nud.), pl. 27, fig. 5. 

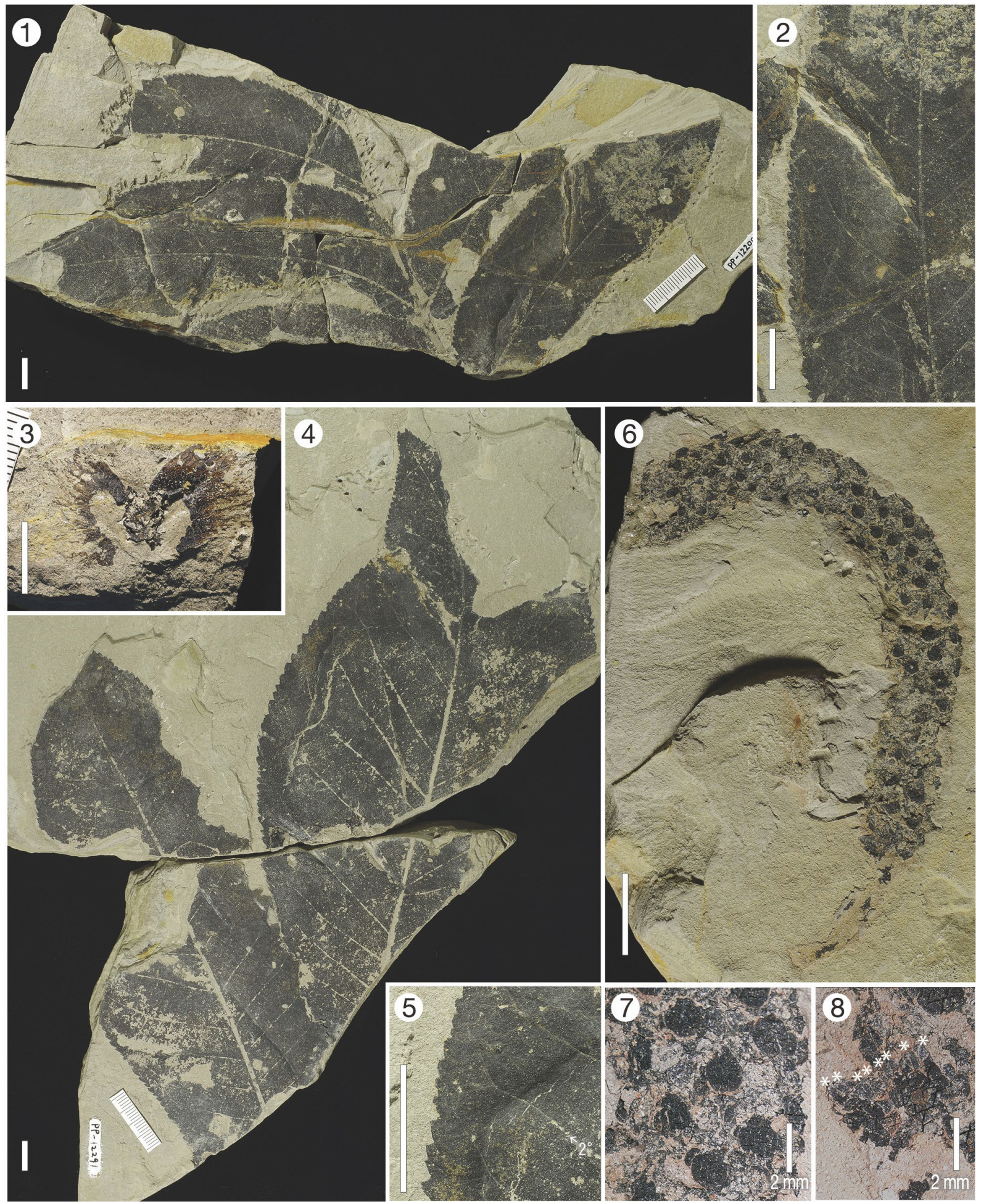

Plate 6. 1, 2, 4, 5. Pterocarya japonica (Tanai) Uemura; 1, 2. leaf, NSM PP-12200, Kn-2; 4, 5. leaf, NSM PP-12291, Kn-1; 3. Pterocarya sp., fruit, NSM PP-12201, Kn-2; 6-8. Betulaceae genus \& species indeterminate, staminate ament, NSM PP-12299, Kn-1. $2^{\circ}$ : secondary vein. " pollen sacs. Scale bars $=1 \mathrm{~cm}$ unless otherwise noted

1988 Alnus protohirsuta Uemura, p. 123-124, pl. 2, fig. 13.

1991 Alnus protohirsuta Endo ex Tanai \& Onoe; Ozaki, p. 142, pl. 10, fig. 9.

2012 Corylus sp. Narita et al., Fig. 5-3.

Materials studied. NSM PP-10464, 10465 (horizon uncertain); NSM PP-12292, 12293,
12295, 12301 (Kn-1) and NSM PP-12302, $12203(\mathrm{Kn}-2)$.

Stratigraphic horizon(s) and occurrence. Kn-1 and Kn-2.

Remarks. The leaves recognized from the Konan flora are variable in shape and size, but 
these specimens are identical to those of Alnus protohirsuta in their general shape, characteristic marginal teeth forming lobations, and compound agrophic veins. This species has been considered a possible ancestor of the extant Alnus hirsuta Turcz. of northern East Asia. Alnus protohirsuta is one of the characteristic species of late Miocene floras from the Japanese Islands.

\section{Alnus sp.}

Pl. 5, figs $7-12$

Materials studied. NSM PP-12290, 12294a, 12294b (Kn-1).

Stratigraphic horizon(s) and occurrence. Kn-1 and Kn-2.

Description. Laminae symmetrical, length 7-11 cm, width 5-7 cm, L:W ratio 1.4-1.6, elliptic to ovate in shape; apex acute, straight; base obtuse, convex, short straight portion near primary vein; petiole missing; margin double serrate; distal flank of tooth straight, proximal flank straight or flexuous; apex acute, with short spiny tip; sinus angular, wide acute to obtuse; secondary vein enters tooth medially; venation pinnate; primary vein thin, straight, slightly sinuous; secondary veins craspedodromous, thin, straight, $\geq 8$ pairs, opposite to subopposite, regularly spaced, diverging from primary vein at $30-45^{\circ}$ on middle portion, recurved near divergence, slightly spreading exmedially; intercostal tertiaries thin, opposite to alternate percurrent, straight or sinuous, obtuse to midvein, vein angle to midvein almost uniform; quaternary veins thin, reticulate, forming polygonal meshes; areoles well developed; veinlets branched once or more.

Remarks. In shape, these leaf fossil specimens are similar to Alnus kefersteinii (Göeppert) Unger from the late-early Miocene Shanwang flora (Hu and Chaney, 1938), but our specimens have less conspicuous marginal teeth. In margin characters and secondary and tertiary venation they also resemble the modern Alnus serrulata (Aiton) Willd. from the eastern United States and Alnus serrulatoides Callier from western Japan, but both of those species show short convex apical parts rather than the cuneate apical parts seen in our specimens. More complete materials are needed to assign them at species level.
Genus: Betula L., 1753

\section{Betula onbaraensis Tanai \& Onoe}

Pl. 7, figs 5-9

1959 Betula cf. schmidtii Regel; Suzuki, p. 32, pl. 2, fig. 1.

1961 Betula onbaraensis Tanai \& Onoe, p. 25, pl. 4, figs $1,2$.

Materials studied. NSM PP-10471 (horizon uncertain); NSM PP-12320 (Kn-1) and NSM PP-12296 (Kn-2).

Stratigraphic horizon(s) and occurrence. Kn-1 and Kn-2.

Description. Laminae symmetrical, length 8-10 $\mathrm{cm}$, width $5-7 \mathrm{~cm}, \mathrm{~L}: \mathrm{W}$ ratio $1.4-1.6$, ovate to elliptic in shape; apex acute, short acuminate; base obtuse, convex; petiole not preserved; margin serrate; teeth compound, one or two subsidiary teeth situated on proximal side of principal tooth, one subsidiary tooth present on distal side, secondary or tertiary vein enter teeth medially; primary tooth flexuous-flexuous; secondary tooth convex or straight, rarely flexuous on proximal side, straight or convex on distal side; tooth apex acute with short, blunt caudate tip; sinuses angular, acute; venation pinnate; primary vein thick, straight; secondary veins craspedodromous, thick, straight, subopposite, $\geq 13$ pairs, evenly spaced, diverging from primary vein at $\sim 45^{\circ}$, angle against primary uniform; 1-2 pairs of basal secondary veins form agrophic veins; tertiary veins distinct, medium in size, opposite-percurrent, convex; quaternary and quintenary veins thick, irregular reticulate, forming polygonal meshes; areoles well developed; veinlets branch once to several times.

Remarks. These specimens clearly correspond to those seen in Betula species with craspedodromous secondary venation and a compound, serrate margin with a short caudate tip. Distinct areoles with branching veinlets are also seen in this genus (Uemura, 1988). Among the Betula species that have been described from the middle to late Miocene in Japan, these specimens are most similar to Betula onbaraensis Tanai \& Onoe of the late Miocene Onbara flora (Tanai and Onoe, 1961) in overall features. Betula onbaraensis has been considered to be related to the extant Betula grossa Siebold \& Zucc., which is native 
to Honshu, Shikoku, and Kyushu in Japan. The current species has been recorded among the late Miocene to Pliocene flora of northern Japan and can be considered a common element of late Miocene forests.

\section{Betula protoglobispica Tanai \& Onoe}

Pl. 8, figs 1-5

1940 Betula ermanni Okutsu, p. 158, pl. 11, figs 1, 2.

1940 Betula globispica Shirai; Okutsu, p. 159, pl. 10, figs 1, 2.

1955 Betula protoermanii Endo (nom. nud.), pl. 28, fig. 3 .

1961 Betula protoglobispica Tanai \& Onoe, p. 24, pl. 3, figs 1, 2.

Materials studied. NSM PP-12297, 12202, 12298, 12321 (Kn-1).

Stratigraphic horizon(s) and occurrence. Kn-1 and Kn-2.

Description. Laminae symmetrical, length $5-11 \mathrm{~cm}$, width $3.5-8 \mathrm{~cm}, \mathrm{~L}: \mathrm{W}$ ratio $1.3-1.4$, ovate to elliptic in shape; apex acute, acuminate; base wide acute, slightly convex with short decurrent base; petiole marginal, stout, 1.8-3.2 cm long; margin doubly serrate; tooth apex acute, blunt, slightly elongated; sinus angular, acute; proximal flank flexuous, distal flank convex or straight; secondary and tertiary vein enter tooth medially; three teeth occur between two secondaries, relatively evenly spaced; venation pinnate; primary vein thin, straight; secondary veins craspedodromous, $\geq 8$ pairs, opposite, diverging from primary vein at $\sim 60^{\circ}$, divergence angle larger proximally; intercostal tertiary veins thin, opposite to alternate percurrent, sinuous or straight, evenly spaced, obtuse to primary, smaller angle proximally; quaternary veins thick, forming well-developed polygonal meshes; veinlets branch several times.

Remarks. Our specimens were assignable to Betula based on their venation, shape and marginal characteristics, especially of the caudate tip. Finely branching veinlets in well-developed areoles also conform to this assignment. Among Betula species from the middle-late Miocene in Japan, these fossil leaves are most similar to Betula protoglobispica Tanai \& Onoe from the Onbara flora (Tanai and Onoe, 1961), based on their laminar shape, slightly decurrent base, doubly serrate margin with short caudate tip, and relatively long petiole. Betula protoglobispica has been recorded among the late Miocene floras of Honshu and Hokkaido in Japan. The current species has a possible affinity with the extant Betula globispica Shirai or Betula ermanii Cham, both of which are found in mountain and alpine forests in Japan. However, Betula protoglobispica differs from these modern species of Betula by having a cuneate base, sharply pointed teeth, and more teeth between the two secondary veins (Uemura, 1988). Considering the environment of extant Betula globispica, Betula protoglobispica probably was a highland element.

Betulaceae genus \& species indeterminate Pl. 6, figs 6-8

Material studied. NSM PP-12299 (Kn-1).

Stratigraphic horizon(s) and occurrence. Kn-1.

Description. Staminate aments, cylindrical in shape, $\sim 8 \mathrm{~cm}$ long, $1 \mathrm{~cm}$ diameter; bracts helically arranged, $\sim 2.0 \mathrm{~mm}$ long, $\sim 1.5 \mathrm{~mm}$ wide, rhomboid or orbicular with round base and short pointed apex; two smaller semicircular bracteoles situated beside each bract; surface texture of bracts or bracteoles is obscure; male flowers probably were attached to stalk admedially, number of flowers uncertain, but at least four pairs of pollen sacs situated at medial side of bract; details of male flowers not observable; peduncle or twig stout, $2.5 \mathrm{~mm}$ wide, at least $2.0 \mathrm{~cm}$ long.

Remarks. Three isolated staminate aments were recovered from $\mathrm{Kn}-1$. One of them bears male flowers with a few pollen sacs on the proximal side of the bract. Because of this, it is probable that this ament was in a sexually mature state. Staminate aments are known in several different families such as Fagaceae (e.g. Quercus, Castanea), Betulaceae, Salicaceae and Myricaceae. In these families, except for the Betulaceae, each flower is more remotely attached to a stalk and the male flowers are more obvious, with long filaments when they are mature. Therefore, we assume that our materials are staminate aments of the Betulaceae family. More well-preserved specimens with details of male flowers are needed to assign them at generic and specific levels. 


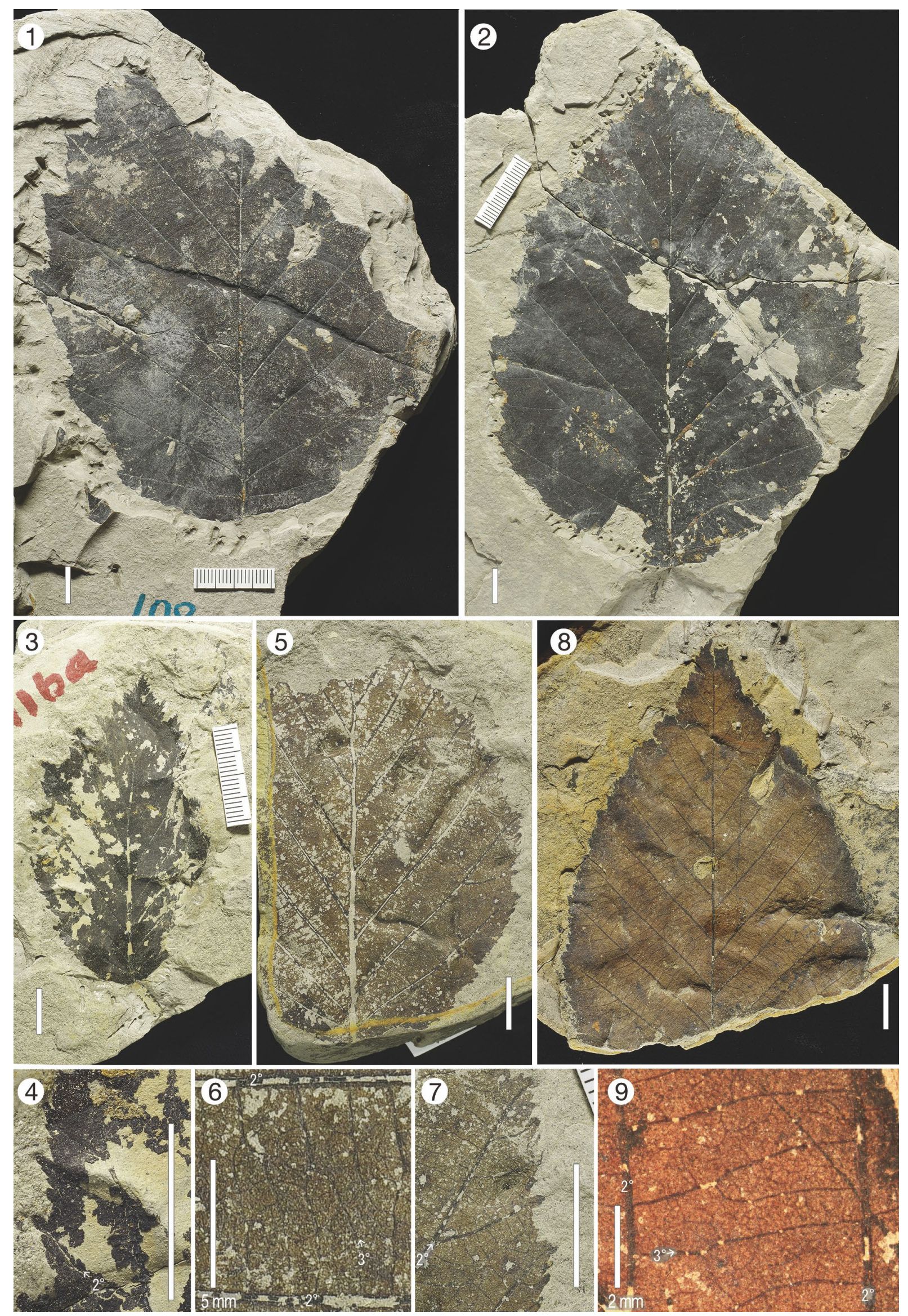

Plate 7. 1-4. Alnus protohirsuta Endo ex Uemura, 1-leaf, NSM PP-12293, Kn-1; 2. leaf, NSM PP-12295, Kn-1; 3, 4. leaf, NSM PP-12203, Kn-2; 5-9. Betula onbaraensis Tanai \& Onoe; 5-7. leaf, NSM PP-12320, Kn-1; 8, 9. leaf, NSM PP-12296, Kn-2. $2^{\circ}$ $\& 3^{\circ}:$ secondary and tertiary veins. Scale bars $=1 \mathrm{~cm}$ unless otherwise noted 
Order: Malpighiales

Family: Salicaceae

Genus: Populus L., 1753

\section{Populus sanzugawaensis}

Huzioka \& Uemura

Pl. 8, figs 6-8; Pl. 9, figs 1-3

1974 Populus sanzugawaensis Huzioka \& Uemura, p. 345 , pl. 2, figs $2-4$; pl. 5, figs 7-9.

Materials studied. NSM PP-10467 (horizon uncertain); NSM PP-12303, 12304a (Kn-1).

Stratigraphic horizon(s) and occurrence. Kn-1 and Kn-2.

Remarks. Our fossil material resembles that of Populus in possessing a pair of thick basal secondary veins rising slightly above the leaf base and regularly arranged round teeth on their margins (i.e. salicoid teeth). Among the Populus species described so far, our materials are most similar to Populus sanzugawaensis Huzioka \& Uemura in their wide elliptic shape, round base, semicraspedodromous secondary veins, a few of which, at the base, typically forked several times toward the margin, although our specimens were about twice larger than the material from northern Honshu (e.g. Huzioka and Uemura, 1974).

This fossil species probably is related to the extant Populus suaveolens Fisch., which lives in cool temperate to sub-boreal regions of northeastern Asia. The current species is common among late Miocene floras of northern Japan, as Uemura (1988) pointed out.

Genus: Salix L., 1753

\section{Salix hokkaidoensis Tanai \& N. Suzuki}

Pl. 9, figs 6-8

1965 Salix hokkaidoensis Tanai \& N. Suzuki, p. 9, pl. 15, fig. 6 ; pl. 16 , fig. 7 .

Material studied. NSM PP-12305 (Kn-1).

Stratigraphic horizon(s) and occurrence. Kn-1 and Kn-2.

Description. Leaf laminae symmetrical, length 8-9 cm, width $2-2.5 \mathrm{~cm}, \mathrm{~L}: \mathrm{W}$ ratio $3.6-$ 4.0 , linear-oblong in shape; apex acute, nearly straight; base obtuse, slightly convex with round or very shallowly cordate end; petiole thick, $\geq 2 \mathrm{~mm}$ long; leaf margin occasionally serrate with tiny indistinct teeth; teeth widely spaced at intervals of $\sim 4 \mathrm{~mm}$, slightly convex on both sides; teeth apices round; tooth major veins not observable; sinuses acute, round; venation pinnate; primary vein stout, nearly straight, tapering toward apex; secondary veins eucamptodromous, $\geq 8$, subopposite to alternate pairs, irregularly spaced, diverging from primary vein at $\sim 30^{\circ}$, straight near middle, considerably incurved, slenderly creeping up along margin; one intersecondary vein in each costa, thin, divergent angle slightly larger than contiguous secondary veins; intercostal tertiary veins indistinct, percurrent, weakly sinuous, oblique to midvein; higherorder venations not seen.

Remarks. The four leaves recognized in our materials are linear-oblong and sparsely bear salicoid teeth on their margins. These features are similar to those of Salix hokkaidoensis Tanai \& N. Suzuki originally described from the late Miocene Shanabuchi flora in northern Hokkaido, Japan. This species is considered to be related to extant Salix koriyanagi Kimura ex Goerz, which is native to Korea and widely cultivated in Japan. This species has been recorded among the late Miocene-Pliocene flora of Hokkaido and northern and central Honshu in Japan (e.g. Tanai and N. Suzuki, 1965) and can be regarded as a common element of the Mitoku-type flora.

\section{Salix misaotatewakii Tanai \& N. Suzuki}

Pl. 9, figs 4, 5, 9-11

1965 Salix misaotatewakii Tanai \& N. Suzuki, p. $10-11$, pl. 2, fig. 6 ; pl. 4 , fig. 2.

2012 Salix sp. Narita et al, Fig. 5-6.

Materials studied. NSM PP-12306, 12199, 12485 (Kn-1).

Stratigraphic horizon(s) and occurrence. Kn-1 and Kn-2.

Description. Leaf laminae slightly asymmetrical, $5-12 \mathrm{~cm}$ long by $2-5 \mathrm{~cm}$ wide (i.e. $\mathrm{L}: \mathrm{W}$ ratio $2.5-4.0$ ), narrow elliptic in shape; apex acute, sinuous, slightly falcate, tip round; base acute, convex; petiole marginal, stout, thick, $\geq 1 \mathrm{~cm}$ long; margin nearly entire, occasionally with tiny teeth; distal tooth flank straight; proximal flank straight or concave; tooth apex acute with globose tip, supplied with secondary veins probably medially; 

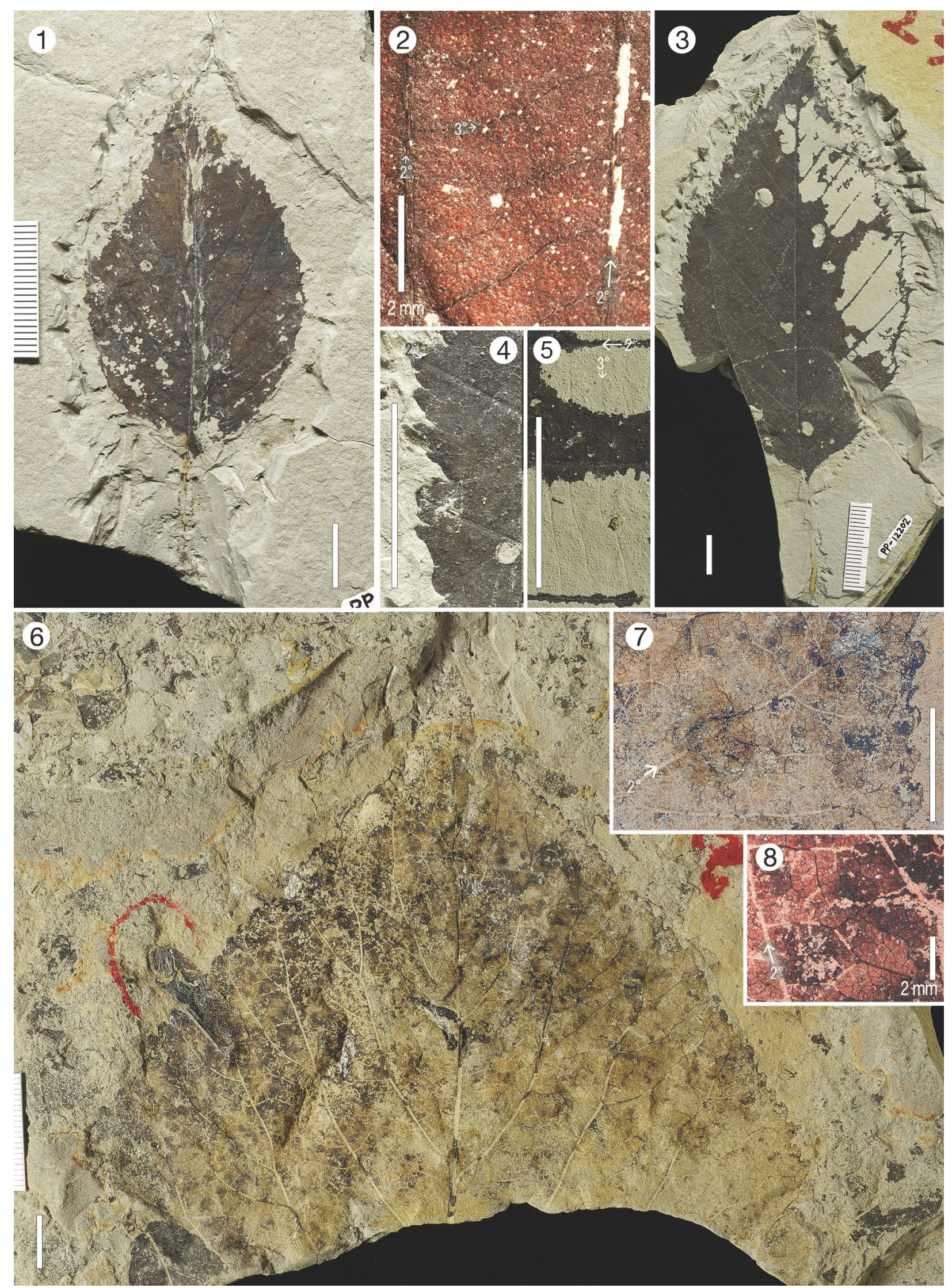

Plate 8. 1-5. Betula protoglobispica Tanai \& Onoe; 1, 2. leaf, NSM PP-12298, Kn-1; 3-5. leaf, NSM PP-12202, Kn-1; 6-8. Populus sanzugawaensis Huzioka \& Uemura, leaf, NSM PP-12304a, Kn-1. $2^{\circ} \& 3^{\circ}$ : secondary and tertiary veins. Scale bars $=1 \mathrm{~cm}$ unless otherwise noted 

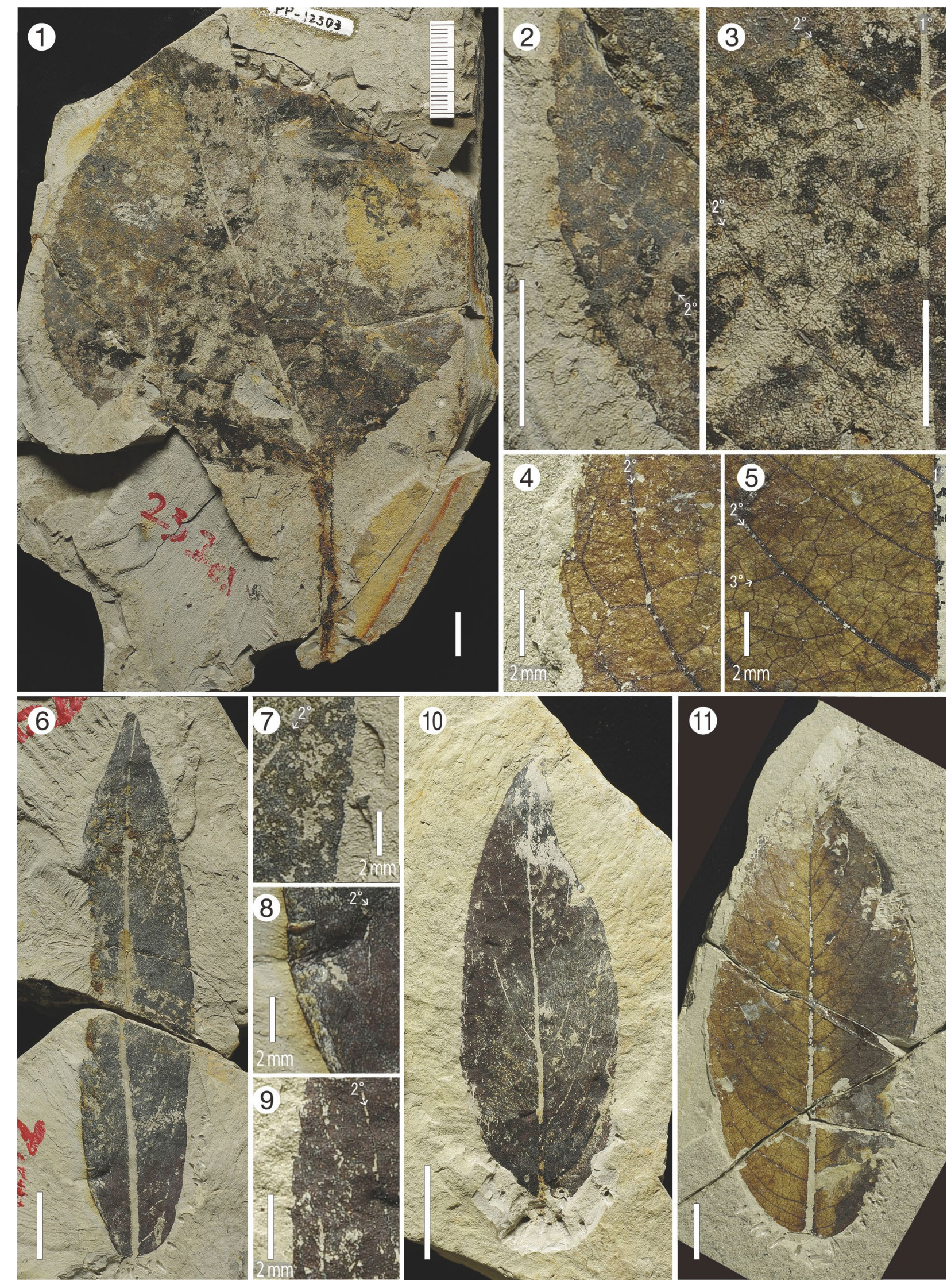

Plate 9. 1-3. Populus sanzugawaensis Huzioka \& Uemura, leaf, NSM PP-12303, Kn-1; 4, 5, 9-11. Salix misaotatewakii Tanai \& N. Suzuki; 4, 5, 11. leaf, NSM PP-12199, Kn-1; 9, 10. leaf, NSM PP-12306, Kn-1; 6-8. Salix hokkaidoensis Tanai $\&$ N. Suzuki, leaf, NSM PP-12305, Kn-1. $1^{\circ}, 2^{\circ} \& 3^{\circ}$ : primary, secondary and tertiary veins. Scale bars $=1 \mathrm{~cm}$ unless otherwise noted 
sinuses angular, acute; venation pinnate; primary vein stout, nearly straight on basal side of laminae, tapering toward apex, slightly sinuous along apical part of laminae; secondary veins semicraspedodromous, thin, $\geq 7$ subopposite to alternate pairs, irregularly spaced, diverging from primary vein at $30-45^{\circ}$, decurrent at divergence, smoothly curved, slenderly creeping up along margin, sending off minor secondary or tertiary veins toward margin, rarely connected with upper secondary vein; 2-3 intersecondary veins in each costa, thin, short, divergent angle against primary vein slightly larger than contiguous secondary veins; tertiary veins thin, percurrent, straight, evenly spaced, nearly parallel to midvein on basal part, obtuse on other parts; quaternary and quintenary veins thick, random reticulate or orthogonal, forming polygonal areoles of irregular size; areoles well developed; veinlet thin, branching several times.

Re m arks. These willow specimens are identical to Salix misaotatewakii Tanai \& N. Suzuki in leaf shape, features of the marginal teeth, and venation, especially the divergent angle of the secondary veins. This fossil species was described from the same fossil assemblage as Salix hokkaidoensis, which was described previously. This species is distinct from the latter by having a narrow elliptic shape, acute convex base, and nearly entire margin. Salix misaotatewakii is very similar to the extant Salix gracilistyla Miq., which is common in riparian forests of Japan (ranging from Hokkaido to Kyushu), Korea and China. This species is common among the late Miocene and subsequent floras of Hokkaido (e.g. Tanai and N. Suzuki, 1965).

Salix palaeofutura Narita, A. Yabe, Uemura \& Matsumoto sp. nov.

Pl. 10, figs $1-5$

Diagnosis. Leaf laminae variable in size, sometimes reaching $20 \mathrm{~cm}$ in length, elliptic to narrow elliptic or oblong in shape; apex acute, straight; base obtuse to right-angled, convex; petiole stout, long, $<4.2 \mathrm{~cm}$; margin serrate to crenato-serrate with irregularly spaced teeth; tooth apex blunt or spinose, oriented obliquely upward; venation pinnate; secondary veins semicraspedodromous, thin, irregularly spaced, diverging from primary veins constantly at middle acute angle, angle uniform, often decurrent, curved, forming series of marginal loops, sending off weak secondary veins to marginal teeth; intersecondary veins present, diverging at same or slightly larger angles than contiguous secondary veins; tertiary veins thin, distinct, percurrent, sinuous, evenly spaced, obtuse to midvein, uniform throughout blade; higher-order veins thick, orthogonal, forming quadrangular meshes; areoles well developed; veinlets thin, branching several times.

Holotype. NSM PP-12315 (Pl. 10, figs 3-5).

Etymology. The epithet refers to its resemblance to the modern species Salix futura Seemen.

Type locality. Konan, Shibetsu City, Hokkaido.

Stratigraphy. Kn-1, Konan Tuffaceous Sandstone and Mudstone Member of the Bifuka Formation

Age. late Middle Miocene.

Paratype. NSM PP-12316 (Pl. 10, figs 1, 2), $\mathrm{Kn}-2$.

Other material studied. NSM PP-12486 (Kn-1).

Stratigraphic horizon(s) and occurrence. Kn-1 and Kn-2.

Description. Leaf laminae slightly asymmetrical, length $12-20 \mathrm{~cm}$, width $5.2-6 \mathrm{~cm}$, $\mathrm{L}: \mathrm{W}$ ratio 2.5-3.0, elliptic to narrow elliptic or oblong in shape; apex acute, straight; base obtuse to right-angled, convex; petiole marginal, long, thick, $<4.2 \mathrm{~cm}$ long, $\sim 2.5 \mathrm{~mm}$ wide at base; margin serrate to crenato-serrate; teeth irregularly spaced; distal flank of tooth concave, proximal flank flexuous, rarely straight; tooth apex acute with blunt apex, often with spinose apex; sinuses round, wide acute; teeth medially supplied by principal vein; venation pinnate; primary vein stout, nearly straight on basal side of laminae, tapering toward apex; secondary veins semicraspedodromous, thin, arranged in $\geq 14$ subopposite to alternate pairs, irregularly spaced, diverging from primary vein constantly at $45-60^{\circ}$, with basal few pairs decurrent at divergence, smoothly curved, forming a series of loops, sending off branches to marginal teeth; intersecondary veins thin, diverging at same or slightly larger angles than contiguous secondary veins, 


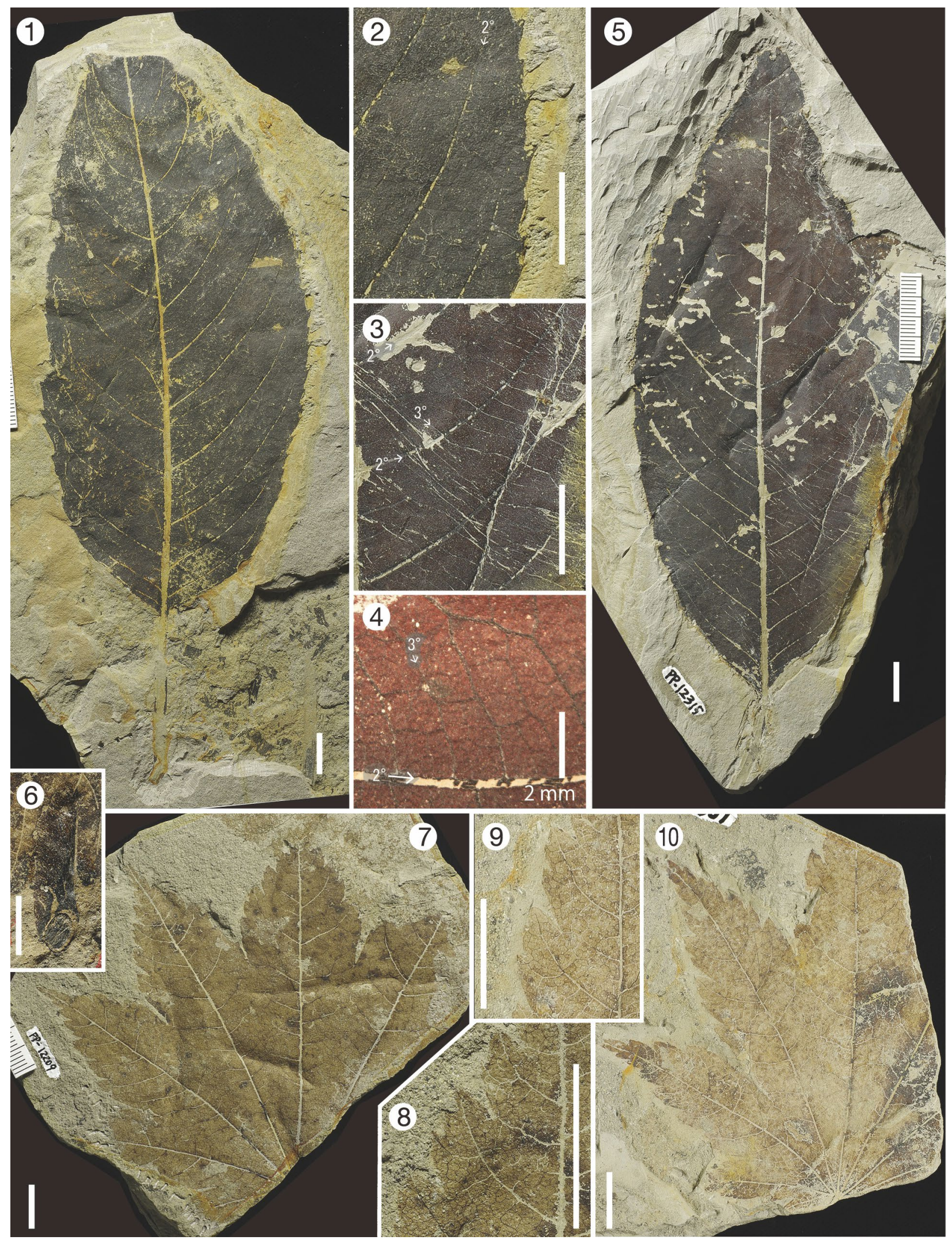

Plate 10. 1-5. Salix palaeofutura Narita et al., sp. nov.; 1, 2. leaf, NSM PP-12316, Kn-2; 3-5. leaf, NSM PP-12315, Kn-1; 6-10. Acer protojaponicum Tanai \& Onoe; 6. samara, NSM PP-12304b, Kn-1; 7, 8. leaf, NSM PP-12209, Kn-2; 9, 10. leaf, NSM $\mathrm{PP}-12307, \mathrm{Kn}-1.2^{\circ} \& 3^{\circ}$ : secondary and tertiary veins. Scale bars $=1 \mathrm{~cm}$ unless otherwise noted 
smoothly curved, extending $<50 \%$ to margin; tertiary veins thin, distinct, percurrent, sinuous, evenly spaced, obtuse to midvein uniformly throughout blade; quaternary and quintenary veins thick, orthogonal, forming quadrangular meshes; areoles well developed; veinlets thin, branching several times.

Comparison. Our specimens resemble Salix species with petiolate leaves, elliptic to narrow elliptic or oblong shape, with acute apexes and obtuse to cuneate bases, crenato-serrate margins, semicraspedodromous secondary veins, and the presence of intersecondary veins. They have long petioles, irregularly spaced secondary veins arising at wide acute angles from the primary vein, uniformly oriented percurrent intercostal tertiary veins, and a crenato-serrate margin. Some of the specimens are very large.

The combination of such characteristics described above is completely unique and differs from that of any species described from the Cenozoic in Japan (Tab. 3). Therefore, we propose a new fossil species, Salix palaeofutura. This species bears some similarity to Salix misaotatewakii from the same site but differs by having a wider divergent angle of the secondary veins, and a crenato-serrate margin with irregularly spaced spinose teeth. It is also separable from Salix hokkaidoensis and Salix parasachalinensis Tanai \& N. Suzuki due to the overall shape of the lamina. In its overall characteristics this species resembles the modern Salix futura, which is endemic to hilly or mountainous regions of central Honshu in Japan, but it differs from Salix futura by having a higher number of secondary veins, a crenato-serrate margin and a longer petiole (Tab. 3). Salix palaeofutura is especially distinguishable from the modern species by its spinose teeth.

Order: Sapindales

Family: Sapindaceae

Genus: Acer L., 1753

Section: Palmata Pax

Acer protojaponicum Tanai \& Onoe

Pl. 10, figs 6-10

1955 Acer protojaponicum Tanai, pl. 17, figs 11, 12. 1959 Acer protojaponicum Tanai \& Onoe, p.281, pl. 6, figs $5,7,8$.
Materials studied. NSM PP-10469 (horizon uncertain); NSM PP-12307, 12304b (Kn-1) and NSM PP-12209 (Kn-2).

Stratigraphic horizon(s) and occurrence. Kn-1 and Kn-2.

Remarks. It has many 9-11-lobed leaves with a doubly serrate margin and deeply cordate bases, samaras having a thick, globose seed, and the samaras diverging $120-180^{\circ}$, which characters are clearly identical to Acer protojaponicum Tanai \& Onoe of Section Palmata Pax. This species was first described from the earliest Miocene Shichiku flora (Tanai and Onoe, 1959) and has been recorded among early to late Miocene floras in Japan. Acer protojaponicum is quite similar to the extant Acer japonicum Thunb., which is common in slope forests of Japan, ranging from Hokkaido to western Honshu.

\section{Section: Platanoidea Pax}

\section{Acer rotundatum Huzioka}

Pl. 11, figs $1-4$

1943 Acer rotundatum Huzioka, p. 129, pl. 24, figs 1-3; pl. 25, fig. 2.

Materials studied. NSM PP-12309, leaf (Kn-2).

Stratigraphic horizon(s) and occurrence. Kn-1 and Kn-2.

Des cription. Leaf lamina symmetrical, palmately 9-lobed, length $5-15 \mathrm{~cm}$, width $4-22 \mathrm{~cm}$, $\mathrm{L}: \mathrm{W}$ ratio $0.7-1.25$, oblong to elliptic in shape, shallowly incised; sinuses obtuse, round; apex acute, straight or acuminate; base reflexed, lobate; petiole marginal, thick, $\geq 2 \mathrm{~cm}$ long; margin entire, slightly sinuous; venation palmate, basally actinodromous with 9 primary veins; primary vein stout, straight; secondary veins thin, $\geq 8$ pairs, opposite to subopposite on each lobe, regularly spaced, diverging from primary vein at $\sim 60^{\circ}$, curving upward toward margin, eucamptodromous, sometimes becoming brochidodromous distally; intersecondary veins distinct; tertiary veins diverging from secondary veins at $80-100^{\circ}$, irregularly reticulate; quaternary veins diverging from tertiary veins at nearly right angles, irregular reticulate; quintenary veins thin, forming quadrangular to polygonal areoles; areoles well developed; veinlets absent, simple or rarely branching once. 


\begin{tabular}{|c|c|c|c|c|c|c|c|c|c|c|c|c|c|c|}
\hline 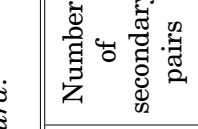 & $\underset{\Lambda 1}{H}$ & 蛹 & $\underset{i}{\stackrel{9}{1}}$ & $i$ & $\frac{10}{1}$ & $\begin{array}{l}\stackrel{\sim}{N} \\
\Lambda 1\end{array}$ & 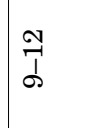 & $\frac{7}{1}$ & $\begin{array}{l}10 \\
1 \\
0\end{array}$ & $\underset{1}{2}$ & 웃 & $\begin{array}{l}\text { ô } \\
\text { ô }\end{array}$ & $\stackrel{\oplus}{N}$ & $\stackrel{20}{\Lambda}$ \\
\hline 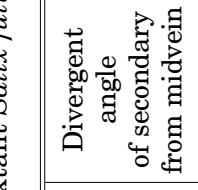 & \begin{tabular}{l}
0 \\
0 \\
10 \\
10 \\
\hdashline
\end{tabular} & 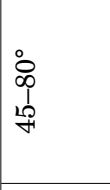 & $\begin{array}{l}\text { in } \\
\text { f } \\
\text { a }\end{array}$ & $\begin{array}{l}7 \\
\vdots \\
\vdots \\
17 \\
\infty\end{array}$ & $\begin{array}{l}0 \\
0 \\
0 \\
0 \\
0\end{array}$ & $\begin{array}{l}i 0 \\
0 \\
10 \\
10 \\
10\end{array}$ & $\begin{array}{l}0 \\
0 \\
0 \\
o \\
o\end{array}$ & $\begin{array}{l}0 \\
0 \\
0 \\
0 \\
0 \\
\infty\end{array}$ & $\begin{array}{l}0 \\
0 \\
0 \\
0 \\
10\end{array}$ & 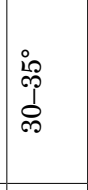 & $\begin{array}{l}i 0 \\
0 \\
0 \\
0 \\
\infty\end{array}$ & $\begin{array}{l}0 \\
0 \\
0 \\
1 \\
1\end{array}$ & $\begin{array}{l}0 \\
0 \\
10 \\
10\end{array}$ & $\begin{array}{l}i \\
\infty \\
0 \\
0 \\
0\end{array}$ \\
\hline 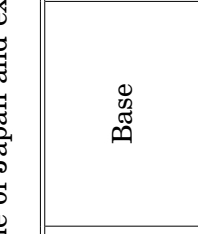 & 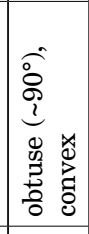 & 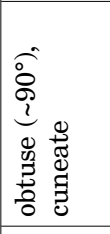 & 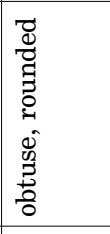 & 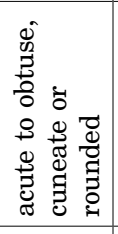 & 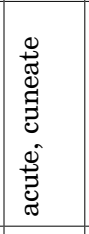 & 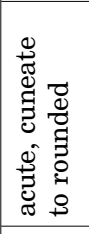 & 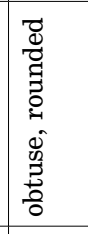 & 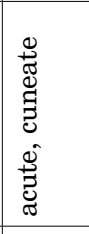 & 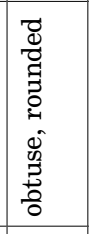 & 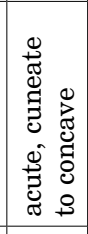 & 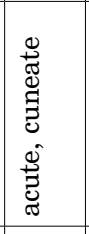 & 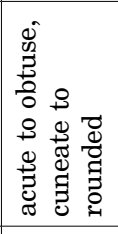 & 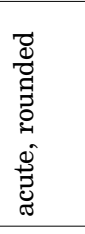 & 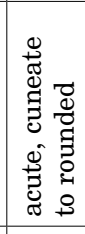 \\
\hline 离 & 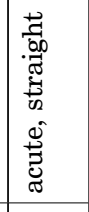 & 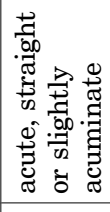 & 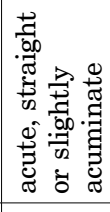 & 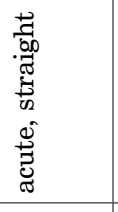 & 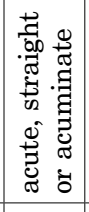 & 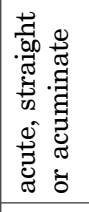 & 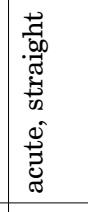 & 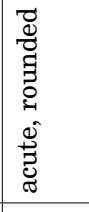 & 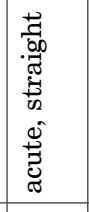 & 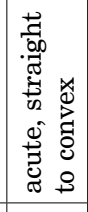 & 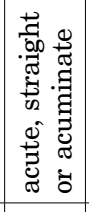 & 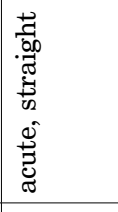 & 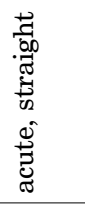 & 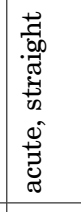 \\
\hline $\begin{array}{l}\text { ये } \\
\text { స్ } \\
\text { ॠ }\end{array}$ & 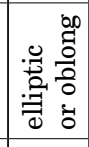 & 若 & 若 & 䓛 & 焗 & 若 & $\begin{array}{l}\infty \\
0 \\
0 \\
0\end{array}$ & 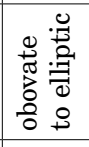 & 总 & 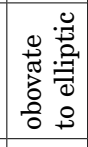 & 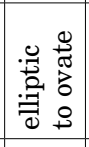 & 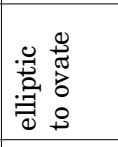 & $\begin{array}{l}\infty \\
\vdots \\
0 \\
0 \\
0\end{array}$ & 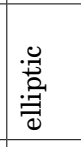 \\
\hline 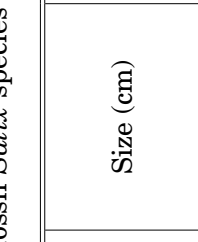 & 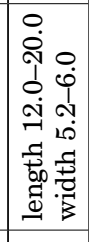 & 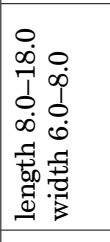 & 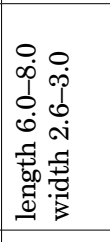 & 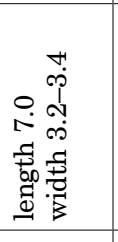 & 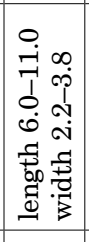 & 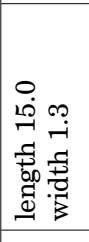 & 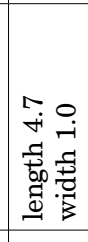 & 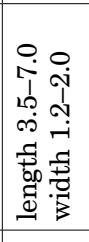 & 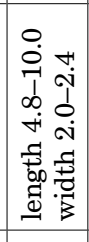 & 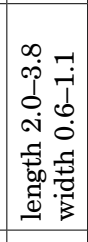 & 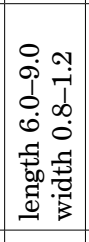 & 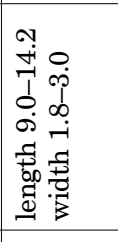 & 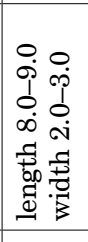 & 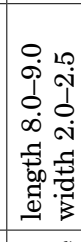 \\
\hline 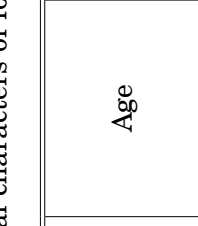 & 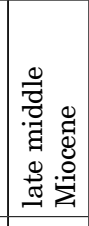 & 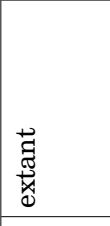 & 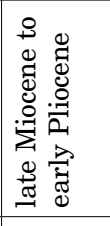 & 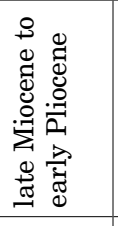 & 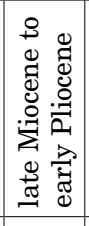 & 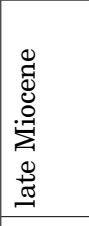 & 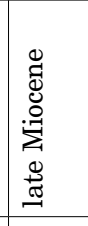 & 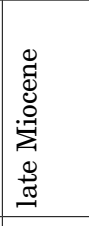 & 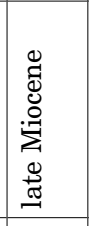 & 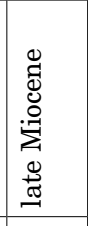 & 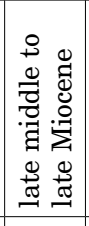 & 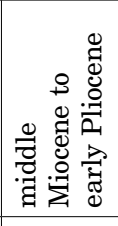 & 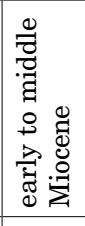 & 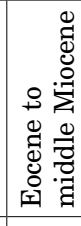 \\
\hline 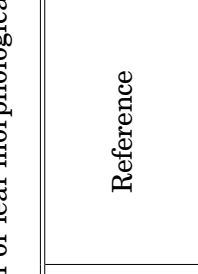 & 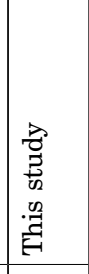 & 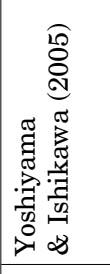 & 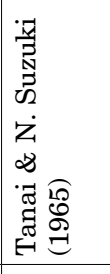 & 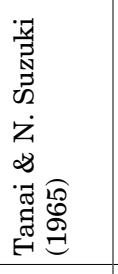 & 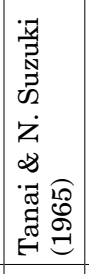 & 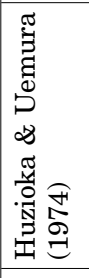 & 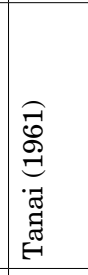 & 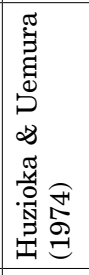 & 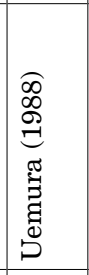 & 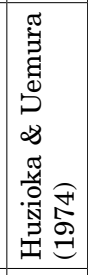 & 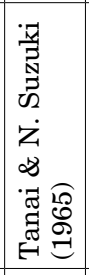 & 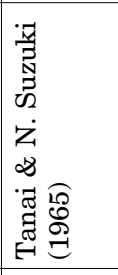 & 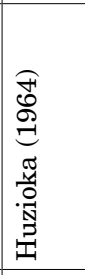 & 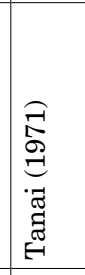 \\
\hline 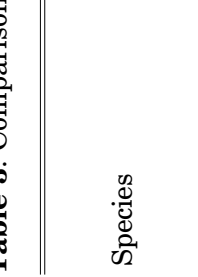 & 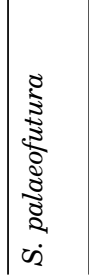 & 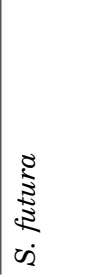 & 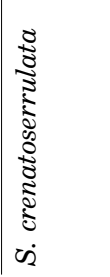 & 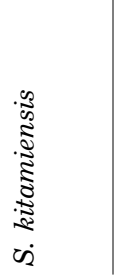 & 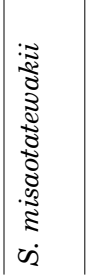 & 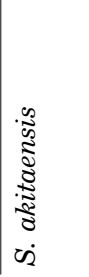 & 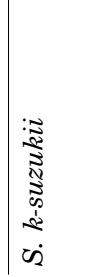 & 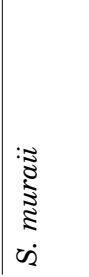 & 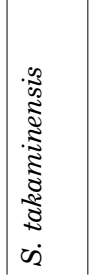 & 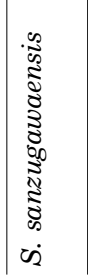 & 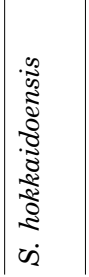 & 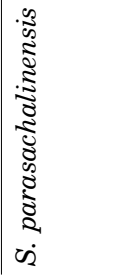 & 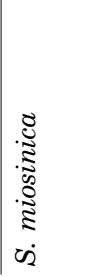 & 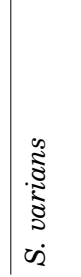 \\
\hline
\end{tabular}

\begin{tabular}{|c|c|c|c|c|c|c|c|c|c|c|c|c|c|}
\hline 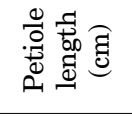 & 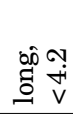 & 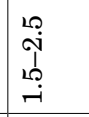 & $\hat{0}$ & 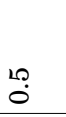 & \begin{tabular}{l}
0 \\
$\stackrel{1}{+}$ \\
\multirow{1}{*}{} \\
- \\
\end{tabular} & 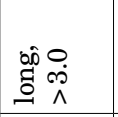 & $\dddot{m}$ & $\begin{array}{l}0 \\
0 \\
0 \\
i\end{array}$ & $\stackrel{\circ}{\stackrel{i}{\Lambda}}$ & $\begin{array}{l}10 \\
0 \\
0 \\
i\end{array}$ & $\begin{array}{l}10 \\
0 \\
0 \\
0 \\
0 \\
0\end{array}$ & $\begin{array}{l}0 \\
\dot{T} \\
0 \\
-i \\
-i\end{array}$ & $\underset{i}{\stackrel{i}{i}}$ \\
\hline 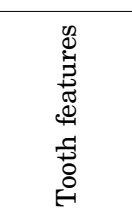 & 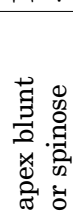 & 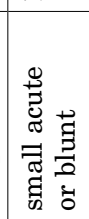 & 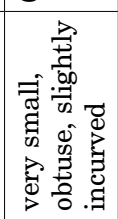 & 1 & 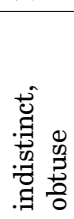 & 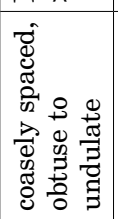 & 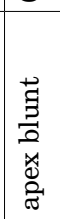 & 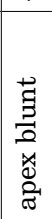 & 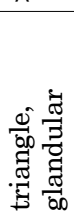 & 芯 & 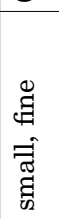 & $\begin{array}{l}\text { न् } \\
\text { ซ్ }\end{array}$ & 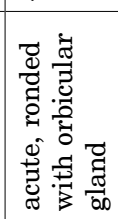 \\
\hline 8 & 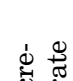 & & $\underset{\sigma}{\stackrel{d}{\sigma}}$ & 承 & 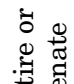 & & 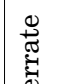 & & 幽 & & $\dot{g}$ & . & \\
\hline
\end{tabular}

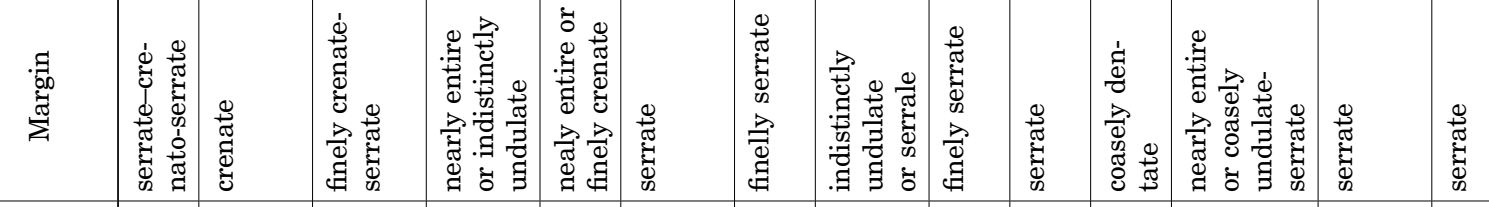




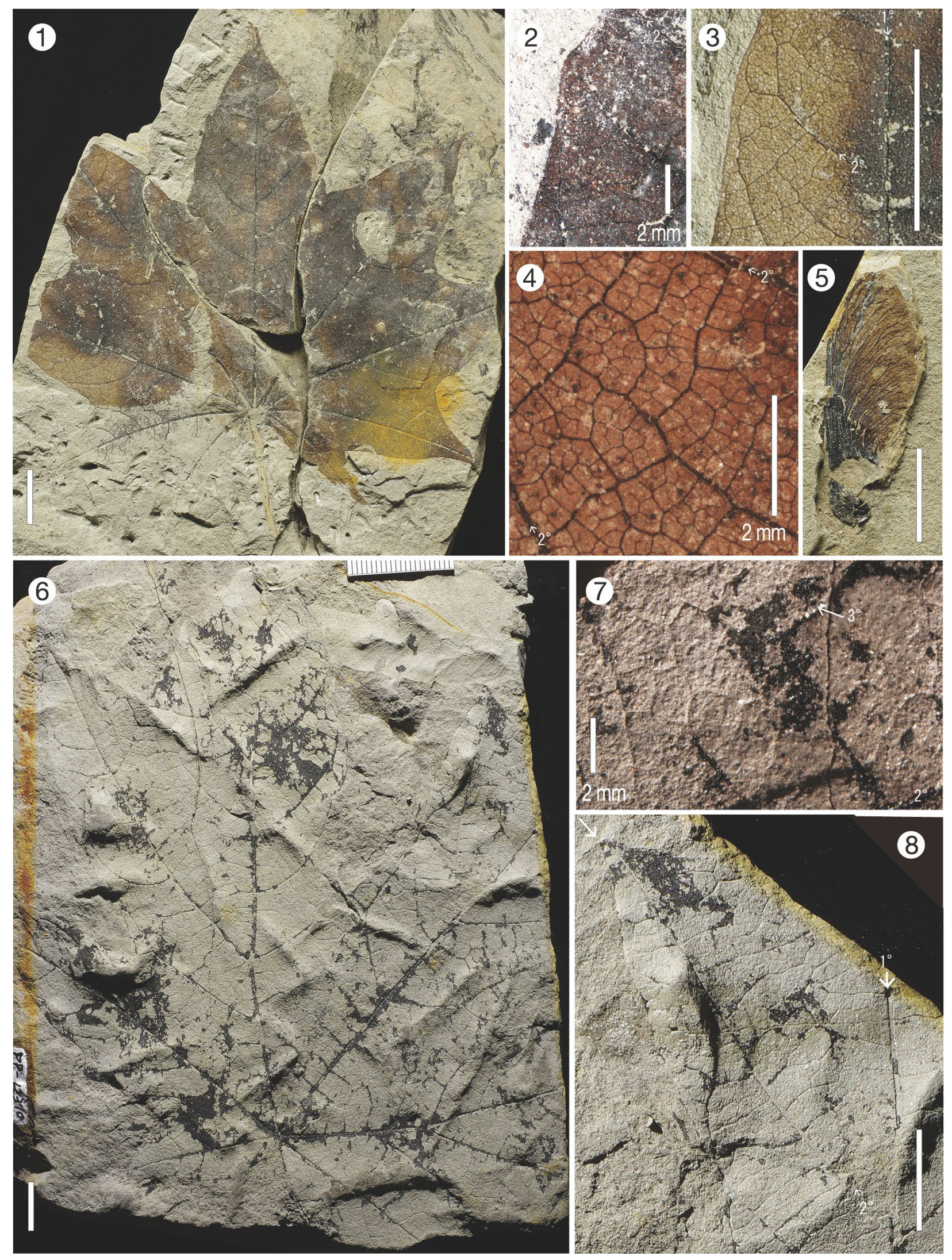

Plate 11. 1-4. Acer rotundatum Huzioka, leaf, NSM PP-12309, Kn-2; 5. Acer sp. cf. A. rotundatum Huzioka, samara, NSM PP-12308, Kn-1; 6-8. Acer sp. cf. A. fatsiaefolium Huzioka, leaf, NSM PP-12310, Kn-2. Arrow in figure 8 points to lobe apex. $1^{\circ}, 2^{\circ} \& 3^{\circ}$ : primary, secondary and tertiary veins. Scale bars $=1 \mathrm{~cm}$ unless otherwise noted 
R e m a r ks. Some nine-lobed leaves with mostly entire margins and deeply cordate bases were identical to those of Acer rotundatum Huzioka in their overall shape, venation, and general lack of freely ending veinlets in well-developed areolation. The species is clearly a constituent of the section Platanoidea Pax (Tanai, 1978).

This fossil species has been recorded among the early Miocene Aniai-type flora in East Asia and is found infrequently among the late Miocene-Pliocene Mitoku-type flora in East Asia (Tanai, 1983).

\section{Acer sp. cf. Acer rotundatum Huzioka}

Pl. 11, fig. 5

\section{Compare:}

1983 Acer rotundatum auct. non Huzioka, Tanai, p. 329-331, pl. 11, figs 3, 6 .

Materials studied. NSM PP-12308(Kn-1).

Stratigraphic horizon(s) and occurrence. Kn-1 and Kn-2.

Description. Samara narrow oblong in general outline, $\sim 27 \mathrm{~mm}$ long, $9 \mathrm{~mm}$ wide; wing obliquely round at apex, $\sim 19 \mathrm{~mm}$ long, outer margin nearly straight, inner margin sinuous, convex apically, straight basally; seed part thin, square-shaped, $\sim 7 \mathrm{~mm}$ long, $6 \mathrm{~mm}$ wide, obliquely oriented against wing; contact scar \pm same width as seed; angle between contact scar and outer margin of wing $\sim 40^{\circ}$.

Remarks. Some isolated samaras were obtained. They resemble Acer rotundatum Huzioka in having a narrow oblong outline and a thin, square-shaped seed, as well as in the divergent angle of the wings from the seed body. Our specimens also resemble the modern Acer pictum Thunb. in those characters. These specimens might be fruits of Acer rotundatum, leaves of which occurred in the same horizon.

Section: Macrophylla

(Polark.) Momotani

\section{Acer sp. cf. A. fatsiaefolium Huzioka}

Pl. 11, figs $6-8$

Compare.

1943 Acer fatsiaefolium Huzioka, p. 131, pl. 23, fig. 1.

Material studied. NSM PP-12310 (Kn-2).
Stratigraphic horizon(s) and occurrence. Kn-1 and Kn-2.

Remarks. Several incomplete specimens with moderately incised, palmately five-lobed leaves were obtained. They possess an entire margin with characteristic dents, and the three central lobes typically decrease in width basally. The specimens superficially resemble Acer fatsiaefolium Huzioka (section Macrophylla) and Acer protomiyabei Endo (section Campestria), both of which have been described from many Miocene fossil sites in Japan and Korea. Species of these two sections can be distinguished from one another based on veinlet features (Tanai, 1978). For example, the areoles of Acer fatsiaefolium are less developed than those of Acer protomiya$b e i$, and the freely ending veinlets of the former divide more than twice, while being either simple or lacking in Acer protomiyabei (Tanai, 1983). The observed veinlets of our specimen, although not very well preserved, are divided several times. Therefore, we tentatively note the strong similarity of our specimens to Acer fatsiaefolium, which was originally described from the early-early Miocene Chianggi flora of South Korea and has been recorded from several localities on the Japanese Islands (Tanai, 1983). Another fossil species in the same section, Acer honshuense Tanai \& Ozaki from the late Miocene Tatsumitoge flora (Tanai and Ozaki, 1977), differs from the current species due to the presence of more elongate-pointed dents. This is the youngest fossil of this species yet recorded.

Section: Indivisa Pax

\section{Acer subcarpinifolium Tanai}

Pl. 12, figs $1-7$

1963 Acer pseudocarpinifolium auct. non Endo, N. Suzuki (part), p. 689. pl. 3, fig. 3.

1983 Acer subcarpinifolium Tanai, p. 347-438, pl. 9, fig. 5 b; pl. 12 , figs $4-5$; pl.13, figs 3,8 ; pl. 14, figs 1-5.

2012 Acer subcarpinifolium Tanai; Narita et al., 2012, figs 4-2, 3.

2017 Acer subcarpinifolium Tanai; Narita et al., 2017, figs 5-13, 14.

Materials studied. NSM PP-10470 (horizon uncertain); NSM PP-12207, 12208, samara (Kn-1) and NSM PP-12311, 12312, leaf $(\mathrm{Kn}-2)$. 

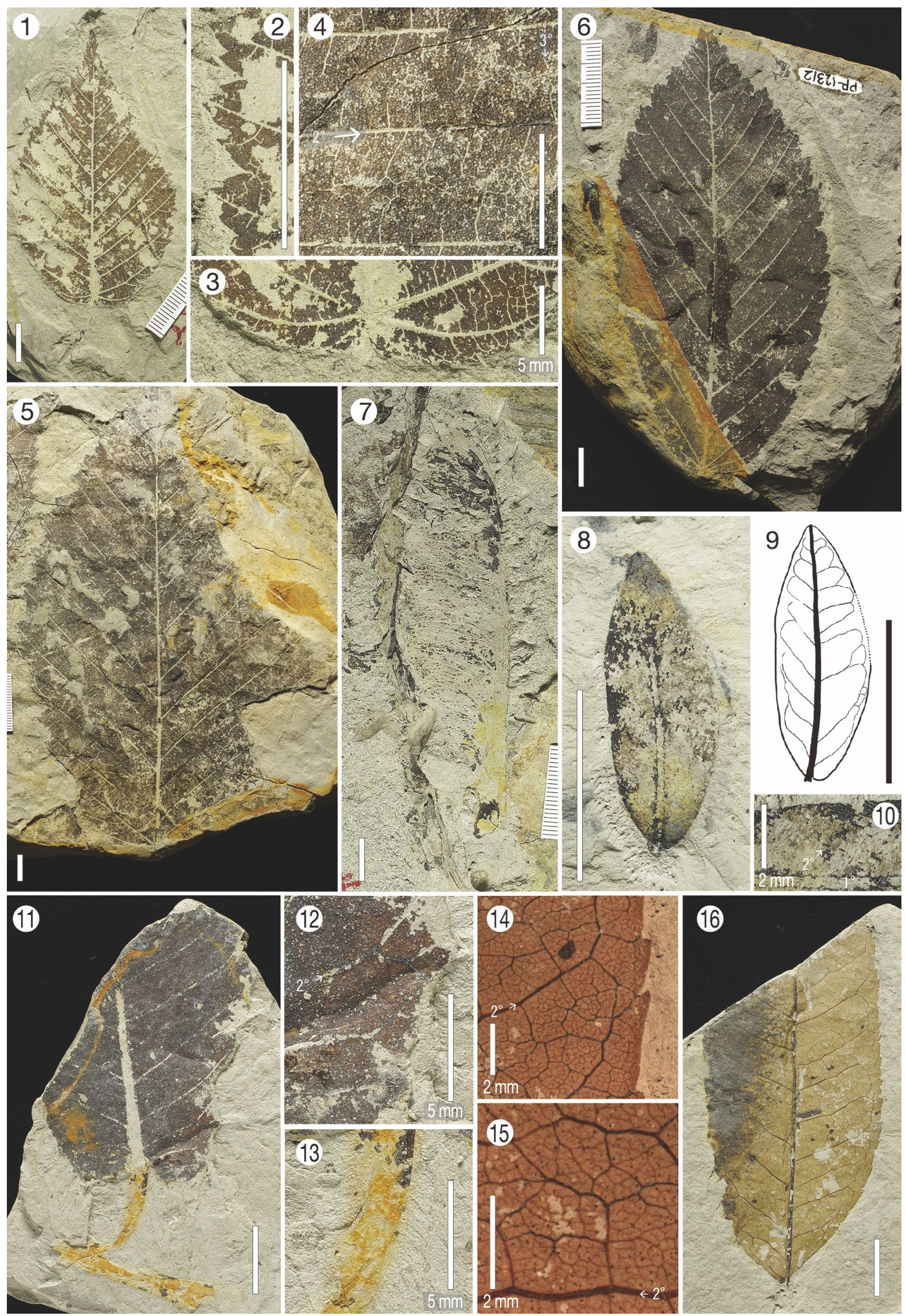

Plate 12. 1-7. Acer subcarpinifolium Tanai; 1-4. leaf, NSM PP-12207, Kn-1; 5. leaf, NSM PP-12311, Kn-2; 6. leaf, NSM PP-12312, Kn-2; 7. samara, NSM PP-12208, Kn-1; 8-10. Rhododendron sp.; 8, 10. leaf, NSM PP-12488, Kn-1; 9, line drawing of 8; 11-13. Actinidia? sp., leaf, NSM PP-12318, Kn-1; 14-16. Fraxinus sp., leaflet, NSM PP-12313, Kn- $2.1^{\circ}, 2^{\circ} \& 3^{\circ}$ : primary, secondary and tertiary veins. Scale bars $=1 \mathrm{~cm}$ unless otherwise noted 
Stratigraphic horizon(s) and occurrence. Kn-1 and Kn-2.

Description. Leaf lamina symmetrical but sometimes basally asymmetrical, length $10-25 \mathrm{~cm}$, width $5-13 \mathrm{~cm}, \mathrm{~L}: \mathrm{W}$ ratio 1.92 2.0, elliptic to wide elliptic in shape; apex acute, acuminate, rarely with prolonged tip; base obtuse, round or shallowly cordate; petiole marginal, length $\geq 1 \mathrm{~cm}$; margin serrate, lobe-like; teeth compound, that is, usually one larger and one smaller tooth situated on proximal side of principal tooth and one smaller tooth on distal side, closely spaced; distal flank of tooth flexuous; proximal flank flexuous or convex; tooth apex acutely pointed, secondary or tertiary vein enters teeth slightly basally; sinuses deep, angular, narrow acute; venation pinnate; primary vein stout, straight or gently curved, gradually tapering toward apex; secondary veins craspedodromous; thick, $\geq 15$ pairs, opposite to subopposite, parallel, regularly spaced, diverging from primary vein at $\sim 45^{\circ}$ on middle portion; a basal pair of secondary veins forming simple agrophic veins end in teeth; tertiary veins thin, irregularly percurrent, originating at right angles on either side of secondary vein, sometimes merging into higher-order reticulum; quaternary and quintenary veins form polygonal areoles of irregular size; veinlets highly irregular in ramification, twice to several times branched, with gradually thinning tips.

Samara large, oblanceolate in general outline, 4-16 cm long, $1-5 \mathrm{~cm}$ wide; $\mathrm{L}: \mathrm{W}$ ratio 3.5-4.5; wing round at apex, outer margin nearly straight, inner margin sinuous, convex apically, straight basally; seed part thick, irregular ellipsoid, $9.6 \mathrm{~mm}$ long, $5.0 \mathrm{~mm}$ wide; contact scar short, $\sim 2 \mathrm{~mm}$ long; divergent angle $\sim 70^{\circ}$.

Remarks. The leaves of this species resemble those of some taxa assigned to the Betulaceae, such as Carpinus and Ostrya. However, our specimens can be distinguished from these taxa by the following features: (1) a deeply incised tooth that often bears subsidiary teeth on either side, resulting in a lobe-like appearance; (2) a pair of slender basal secondary veins being deriving from the base; and (3) irregularly ramified (twice to several times) veinlets in rectangular or polygonal areoles. These features are shared by the extant Acer carpinifolium Siebold \& Zucc., which is endemic to
Japan. Acer carpinifolium represents a monotypic section of Indivisa Pax. A number of samaras associated with the leaves of Acer subcarpinifolium are also very similar to those of Acer carpinifolium in their general shape, seed shape and contact scar feature, although they are at least twice as large as those of the modern species with regard to average size. The leaves of the fossil species can be distinguished from the extant ones by having less acuminate marginal teeth (Tanai, 1983) and fewer secondary veins. This species has been recorded from several late Miocene-Pliocene floras of Hokkaido and northern Honshu, Japan (Tanai, 1983; Uemura, 1988), and can be regarded as an element of the Mitoku-type flora. Our materials clearly represent one of the oldest records of this species and presumably indicate the origin of this section of the genus Acer, which is endemic to Japan.

Recently, leaves from the early Oligocene Kobe Group were reported as Acer sp. cf. A. subcarpinifolium (Yonesaka and Yamamoto, 2004). They are superficially similar to those of Acer carpinifolium and attach oppositely to the twig, which clearly indicates their affinity to the genus. Their relationship to this species should be evaluated to understand the origin of this endemic section in East Asia. Acer subcarpinifolium has often been dominant in riverside deposits of the Nayoro area (Narita et al., 2017). Such fossil occurrences, together with the habitat of the living equivalent of this species, strongly imply that Acer subcarpinifolium probably was one of the most common elements of riparian and lowland vegetation during the late middle Miocene-Pliocene.

Order: Ericales

Family: Actinidiaceae

Genus: Actinidia Lindl., 1836

Actinidia? sp.

Pl. 12, figs $11-13$

Material studied. NSM PP-12318 (Kn-1).

Stratigraphic horizon(s) and occurrence. Kn-1.

Description. Only basal part of lamina with a petiole attached to a branch available. 
Lamina shallowly cordate, serrate with spiny tooth, flexuous-flexuous in shape; medial vein thick, sending semicraspedodromous secondary veins; divergent angle of secondary veins at base nearly perpendicular to primary vein, more acute upward, irregularly arranged; course of secondary veins gently curved, abruptly incurved to form loops, relatively thick minor secondaries arise toward teeth; thick intersecondary veins short, usually present; petiole very thick, short, $\sim 15 \mathrm{~mm}$ long; tiny circular spots and long spines irregularly distributed on surface of petiole and branch (indicating a pilose feature).

Remarks. The specimen was very fragmentary but bears several important features for identification. One such example is the spiny marginal tooth and the presence of long hairs on the petiole and branch. Due to these characteristics, we tentatively designate it Actinidia sp. The specimen differs from modern species such as Actinidia polygama (Siebold \& Zucc.) Planch. ex Maxim., Actinidia arguta (Siebold \& Zucc.) Planch. ex Miq. and Actinidia rufa (Siebold \& Zucc.) Planch. ex Miq. in Japan, by having a relatively short petiole and more conspicuous marginal teeth.

Family: Ericaceae

Genus: Rhododendron L., 1753

\section{Rhododendron sp.}

Pl. 12, figs $8-10$

Material studied. NSM PP-12488 (Kn-1).

Stratigraphic horizon(s) and occurrence. Kn-1.

Description. Leaf pubescent, bearing $\sim 0.4 \mathrm{~mm}$ long hairs throughout; lamina basally asymmetrical, length $15.5 \mathrm{~mm}$, width $5.6 \mathrm{~mm}$, narrow oblong to narrow elliptic in shape; apex acute, straight, very shortly rounded with protruding tip (spinose); base obtuse, convex on one side, slightly cordate on other side; petiole short; margin entire; venation pinnate; primary vein stout, straight; secondary veins brochidodromous, very thin, $\geq 10$ alternate pairs; basal secondary veins situated slightly above leaf base, diverging from primary vein at moderately acute to wide-acute angle, straight or slightly decurrent at divergence; intercostal tertiary veins probably reticulate; higher-order venation not observable.

Remarks. This tiny leaf is assigned to Rhododendron based on a combination of features that includes a spinose apex, entire margin, brochidodromous secondary venation arising slightly above the base, and pubescent surface.

Order: Lamiales

Family: Oleaceae

Genus: Fraxinus L., 1753

Fraxinus sp.

Pl. 12, figs 14-16

Material studied. NSM PP-12313 (Kn-2).

Stratigraphic horizon(s) and occurrence. Kn-2.

Description. Leaflet lamina basally asymmetrical, length $\sim 10 \mathrm{~cm}$, width $5 \mathrm{~cm}$, oblong in outline; apex missing; base obtuse, convex or straight; petiolule marginal, length $\geq 3 \mathrm{~mm}$; margin serrate; distal flank of teeth concave, proximal flank convex, tooth apex acutely pointed, typically incurved; sinuses angular, acute; tooth supplied by principal vein medially; venation pinnate; primary vein stout, straight and slightly sinuous in middle portion; secondary veins semicraspedodromous, thick, $\geq 10$ pairs, alternate or subopposite, nearly parallel, irregularly spaced, diverging from primary vein at $60-80^{\circ}$, straight, slightly sinuous, abruptly curving upward near margin to form loops, sending off thin minor secondary veins to teeth sinuses; tertiary veins thin, irregular reticulate; quaternary veins medium to thick, irregularly reticulate, forming irregular polygonal meshes with tertiary veins; areoles well developed; veinlets thin, branching several times.

Remarks. Only two incomplete specimens were obtained from Kn-2. They are basal inequilateral elliptic in shape, with evenly spaced incurved teeth and having semicraspedodromous secondary veins and well-ramified intercostal venation. Based on these features, they clearly resemble Fraxinus species.

Among the Fraxinus species thus far described, our specimens are similar to Fraxinus takaminensis Uemura, which was described 
from the late Miocene Takamine flora of northern Honshu in Japan due to their shape and the features of venation and marginal teeth (Uemura, 1988). However, we hesitate to assign our materials to this taxon, since we only have fragmentary material without apical halves, and it is difficult to determine its variation.

\section{DISCUSSION}

\section{VEGETATION RECONSTRUCTION}

The plant fossil assemblage from the Bifuka Formation comprises 30 taxa of arboreal angiosperms and gymnosperms, together with one herbaceous monocot. Since the plant-bearing sediments are assumed to have been deposited in a lacustrine environment, the fossil assemblage is clearly allochthonous and possibly derived from several different parts of the landscape, having been transported by river currents and wind, or having fallen from the surrounding forests. Narita et al. (2017) studied plant fossil assemblages from the upper middle to lower Upper Miocene Panke Formation (Kaminayoro flora; Fig. 1), which is a nearly contemporaneous heterotopic facies of the Kawanishi Formation, distributed near the fossil site of this study. They observed that the assemblages apparently accumulated in a riverside environment such as a flood plain, natural levee, abandoned channel or lake environment, and discussed the ecology of their constituents in detail based on several para-autochthonous and allochthonous fossil assemblages. Consequently, four types of plant communities were recognized: (1) riparian vegetation dominated by Cercidiphyllum crenatum, Acer subcarpinifolium and Picea sp. A; (2) swamp vegetation exclusively consisting of Equisetum sp., Picea sp. A, Bambusioideae indet. and Salix sp.; (3) lakeside vegetation consisting of Cercidiphyllum crenatum, Cladrastis chaneyi and Salix sp.; and (4) surrounding slope forest vegetation dominated by Fagus palaeojaponica. Approximately half of the constituents (16/33) of the Kaminayoro flora are common among the contemporaneous Konan flora of this study. Therefore, we assume that the past vegetation of the Konan flora is the same as the Kaminayoro assemblage.

In the Konan flora, Fagus palaeojaponica was the most dominant element and comprised about $46 \%$ of the 2,400 specimens examined. The next dominant species were Acer subcarpinifolium (9.0\%), Picea sp. A (7.3\%), Acer protojaponicum (5.7\%), Salix misaotatewakii (5.9\%), Cladrastis chaneyi (3.6\%), Cercidiphyllum crenatum (3.5\%), Alnus protohirsuta (3.3\%), Betula protoglobispica (3.2\%), Populus sanzugawaensis (2.9\%) and Pterocarya japonica $(2.0 \%)$.

Although the smaller numbers of preserved specimens might be due to a function of distance from the deposition site and preservation potential, Fagus palaeojaponica is inferred to be the dominant species of the Konan flora. The monodominant species, Fagus palaeojaponica, is assumed to be a major constituent of the slope forest vegetation of the area during the late middle Miocene. Picea sp. A, Acer subcarpinifolium and Cercidiphyllum crenatum were elements of the riparian vegetation and often comprise para-autochthonous fossil assemblages in the Kaminayoro flora. Picea sp. A also inhabited swamp vegetation with several willow species. This combination was also recorded in our assemblage. Cladrastis chaneyi was common in our fossil assemblage and may also have been a constituent of lakeside vegetation, along with Cercidiphyllum crenatum and Salix spp. In addition, although they were not major elements, Populus sanzugawaensis and Pterocarya japonica were also constituents of riparian vegetation in the Kaminayoro flora. Based on their living relatives, Alnus protohirsuta and Betula protoglobispica might constitute riparian or slope forest vegetation. Consequently, we assume that the Konan flora is a mixture of source vegetation which was well represented by the lowland and slope forests behind it.

\section{CLIMATIC INTERPRETATION}

Based on the absence of evergreen angiosperms as well as the common occurrence of Fagus palaeojaponica, Picea, Acer, and Betulaceae species, the source vegetation of the Konan flora is comparable to the Mixed Northern Hardwood Forest of East Asia that is distributed in northernmost Honshu and most lowlands in Hokkaido (Wolfe, 1979). The percentage of woody dicotyledons with entire leaf margins in the Konan flora (13.0\%) agrees with the values for this type of forest vegetation (9-24\%; Wolfe, 1979; Tab. 4). The mean 


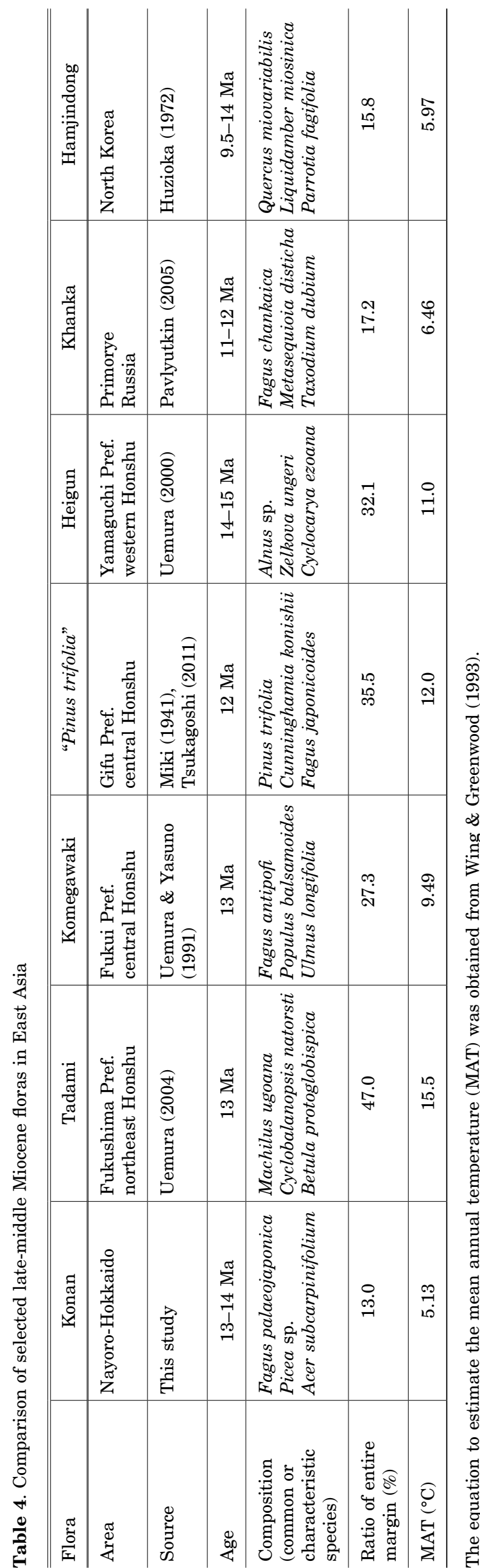

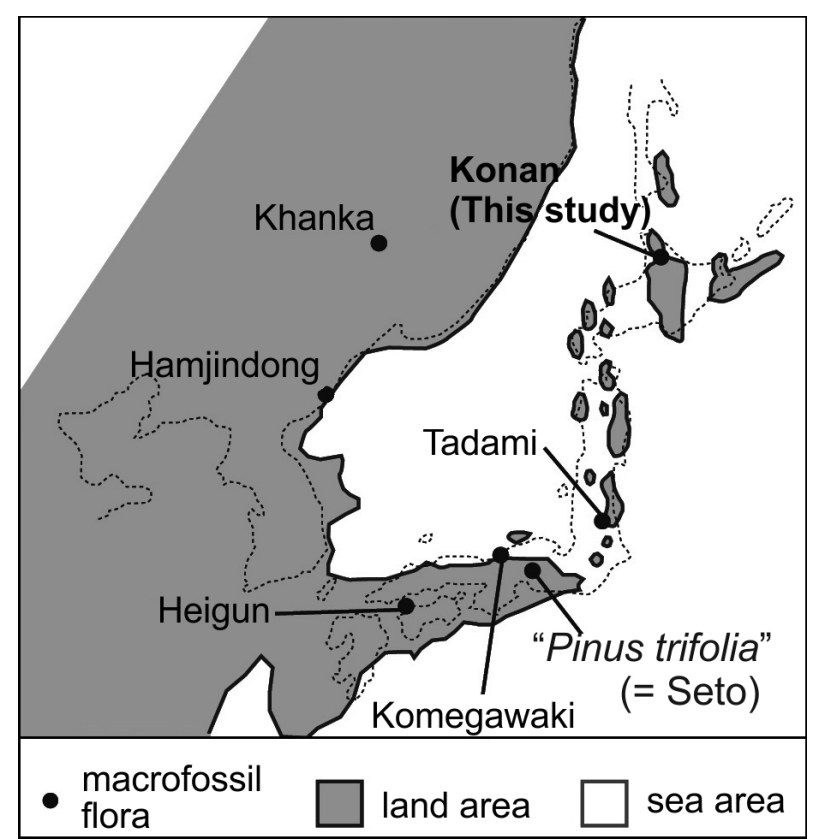

Fig. 2. Distribution of late-middle Miocene floras of East Asia. Paleogeographic map is based on Uemura (1989), Taira (1990), Yahata (1994), Ogasawara \& Uemura (2006) and Tsutsumi (2014)

annual temperature (MAT) of the Konan flora is estimated to be $5.13^{\circ} \mathrm{C}$, based on leaf margin analysis (Tab. 4). In a comparison with the MAT of roughly contemporaneous flora in Japan (Tab. 4), the Konan flora presents the lowest MAT value. Paleogeographically, our site is located in the northernmost latitude in which the compared fossil assemblages appear, and can be ascribed to the same latitudinal temperature gradient as exists today (Fig. 2).

It is obvious that the leaves of some species recognized in the Konan flora were extremely large: for example, Fagus palaeojaponica (Pl. 5, figs 1, 3), Populus sanzugawaensis (Pl. 8, fig. 6), Acer subcarpinifolium (Pl. 12, figs 5, 6), Acer rotundatum (Pl. 11, fig. 1), Alnus protohirsuta (Pl. 7, figs 1, 2) and Salix palaeofutura (Pl. 10, figs 1, 5). This feature has been identified among other floras of the Nayoro area (e.g. Uemura, 1991; Narita et al., 2017), and they were much larger than those of the same species from more southerly areas (e.g. Tanai and Onoe, 1961; Uemura, 1988).

Leaf dimensions are often considered to be related to the humidity of the surrounding environment (e.g. Wolfe and Uemura, 1999); this has also been suggested by multivariate statistical analyses employing CLAMP (Wolfe, 1995). The leaves of the modern Japanese beech (Fagus crenata Blume) are larger in northern areas than in southern areas, while those in 
Table 5. Stratigraphic ranges of the Konan species in Cenozoic strata in Japan and adjacent areas

\begin{tabular}{|c|c|c|c|c|c|c|}
\hline Konan species & $\begin{array}{c}\text { Comparable } \\
\text { extant species }\end{array}$ & Paleogene & $\begin{array}{l}\text { Early-early } \\
\text { Miocene }\end{array}$ & $\begin{array}{l}\text { L. early- } \\
\text { e. middle } \\
\text { Miocene }\end{array}$ & $\begin{array}{c}\text { Late } \\
\text { Miocene }\end{array}$ & Pliocene \\
\hline Abies protofirma & A. firma & . & . & . & + & + \\
\hline Picea kaneharai & P. polita & . & . & . & + & + \\
\hline Cercidiphyllum crenatum & C. japonicum & + & + & + & + & + \\
\hline Cladrastis chaneyi & C. platycarpa & . & . & . & + & + \\
\hline Prunus protossiori & P. ssiori & . & . & . & + & + \\
\hline Sorbus lanceolata & S. matsumurae & . & . & . & + & + \\
\hline Sorbus uzenensis & S. commixta & . & + & . & + & + \\
\hline Fagus palaeojaponica & - & . & . & . & + & + \\
\hline Pterocarya japonica & P. rhoifolia & . & . & . & + & + \\
\hline Alnus protohirsuta & A. hirsuta & . & + & . & + & + \\
\hline Betula onbaraensis & B. grossa & . & . & . & + & + \\
\hline Betula protoglobispica & B. globispica/ B. ermanni & . & . & . & + & . \\
\hline Populus sanzugawaensis & P. suaveolens & . & . & . & + & + \\
\hline Salix hokkaidoensis & S. koriyanagi & . & . & . & + & . \\
\hline Salix misaotatewakii & S. gracilistyla & . & . & . & + & + \\
\hline Acer protojaponicum & A japonicum & . & + & + & + & + \\
\hline Acer rotundatum & A. pictum & . & . & + & + & + \\
\hline Acer sp. cf. A. fatsiaefolium & A. macrophyllum & . & + & . & . & . \\
\hline Acer subcarpinifolium & A. carpinifolium & $?$ & . & . & + & + \\
\hline
\end{tabular}

‘' - presence of fossil records

snowy areas are larger than those in less snowy areas (Hagiwara, 1977). The relationship seen in Japanese beech was revealed to be a phenotypic effect caused by changes in water availability across geographic areas (Tateishi et al., 2010). Narita et al. (2012) reported $463 \mathrm{~mm}$ 3 -WET (precipitation during the three wettest months) and $453 \mathrm{~mm} 3$-DRY (precipitation during the three driest months) for the Konan flora based on CLAMP analysis (Wolfe, 1995). They estimated MAP (mean annual precipitation) for the Konan flora to be $1830 \mathrm{~mm}$ based on approximation of 3-WET and 3-DRY. These precipitation data showed that winter precipitation was much higher during the late middle Miocene in this area than in the present day (Narita et al., 2012). The larger leaf sizes seen among the Konan flora may be due to the effect of greater winter precipitation and lower temperatures during that period.

\section{COMPARISON WITH THE MIOCENE FLORAS IN JAPAN AND ADJACENT AREAS}

Miocene floras in Japan are divided into three types: Aniai-type, Daijima-type and Mitokutype, in order of appearance. The compositional changes in these floral types have been considered to be related to changes in climatic conditions and geographic configurations (Pavlyutkin et al., 2016). Both the Aniai-type and Mitokutype floras in Honshu (central Japan) represent deciduous forest vegetation that is comparable to that of Mixed Northern Hardwood Forest; however, the constituents of the two floras differ from each other (Tanai, 1961). Most floral constituents change in species level (Tanai, 1992). In the Konan assemblage, the majority of constituents consist of late Miocene-Pliocene species known as elements of the Mitoku-type flora, with fewer early-middle Miocene floral elements (Tab. 5). It is therefore clear that the Konan flora represents a transitional assemblage comprised of early-middle Miocene and late Miocene-Pliocene species (Tab. 5).

While the Konan flora is quite limited in number, there are few fossil assemblages that are nearly contemporaneous with it (Fig. 2; Tab. 4): the Tadami flora of Fukushima Prefecture, south of northeastern Honshu (Uemura, 2004); the Komegawaki flora of Fukui Prefecture in central Honshu (Uemura and Yasuno, 1991); and the Heigun flora of Yamaguchi Prefecture in southwestern Honshu (Uemura, 2000). Contrary to what is observed in the Konan flora, these floras consist exclusively of early Miocene species such as Fagus antipofi, Ulmus longifolia and Cyclocarya ezoana (Tab. 4), and mostly represent vegetation established under warm climatic conditions. Thus, we can assume that the modernization of forest elements, which is especially apparent in the Mitoku-type flora, probably started 
earlier in northerly areas than previously thought, under cool and humid climate conditions (e.g. Tanai, 1992). Similar trends are also seen in Sea of Japan areas, where cooler temperate Mixed Broad-leaved Deciduous Forest has been recorded (Khanka flora: Pavlyutkin, 2005; Hamjindong flora: Huzioka, 1972). The former is represented by an abundance of a single beech species, Fagus khankaica Alexeenko, while the latter contains Fagus antipofi and Fagus palaeojaponica (reported as Fagus protojaponica Suzuki).

In more southerly areas, the so-called Pinus trifolia flora (Miki, 1941; = Seto flora: Ozaki, 1991) is almost contemporaneous with the Konan flora (12-10 Ma: Tsukagoshi, 2011). It represents a warmer temperate vegetation consisting of various relict elements (e.g. Cunninghamia, Keteleeria, Liquidambar), together with some taxa that were identified as extant species (Alnus japonica Siebold \& Zucc., Carpinus carpinoides Makino). Further research is needed for a proper grasp of the modernization of the floras that occurred in southerly areas.

\section{ACKNOWLEDGEMENTS}

We are grateful to Dr. Hideki Takahashi (Hokkaido University Museum) for his advice, and to Dr. Hiroyuki Sato (Hokkaido University Museum) for his help in storing our fossil specimens. Thanks are also due to Dr. Ben LePage (The Academy of Natural Science) for English proofreading of the submitted manuscript, and to two anonymous reviewers, the section editor and line editor for their suggestions and constructive comments, which greatly improved the paper.

\section{REFERENCES}

Brown, R.W., 1935. Miocene leaves, fruits, and seeds from Idaho, Oregon, and Washington. Journal of Paleontology 9(7), 572-587.

Ellis, B., Daly, D.C., Hickey, L.J., Johnson, K.R., Mitchell, J.D., Wilf, P., Wing, S.L., 2009. Manual of Leaf Architecture Cornell University Press, Ithaca, New York.

Endo, S., 1955. Icones fossil plants from the Japanese Islands Sangyo-Tosho, Tokyo. [in Japanese].

Goto, Y., Nakagawa, M., Wada, K., 1995. Tectonic setting of the Miocene volcanism in northern Hokkaido, Japan: Speculation from their K-Ar ages and major element chemistry. Journal of Mineralogy, Petrology and Economic Geology 90, 109-123. [in Japanese with English summary].

Group, T.A.P., 2016. An update of the Angiosperm Phylogeny Group classification for the order and families of flowering plants: APG IV. Botanical Journal of the Linnean Society 181, 1-20.

Hagiwara, S., 1977. Leaf area cline recognized in Fagus crenata. The Study of Species Biology 1, 39-51. [in Japanese].

Hashimoto, W., Nagao, S., Kanno, S., 1965. Explanatory text of the Geological map of Japan, scale 1:50,000, Soeushinai (Asahikawa-35) Geological Survey of Hokkaido. [in Japanese with English summary].

Heer, O., 1859. Flora Tertiaria Helvetiae die Tertiäre Flora der Schweiz Verlag der Lithographischen Austalt von J. Wurster \& Compagnie, Winterthur.

Heer, O., 1869. Miocene baltische Flora. Beiträge zur Naturkunde Preussens 2, 1-104, pls. 101-156, Miocene paleogeographic map of Europe.

Hickey, L.J., Peterson, R.K., 1978. Zingiberopsis, a fossil genus of the ginger family from Late Cretaceous to early Eocene sediments of Western Interior North America. Canadian Journal of Botany 56, 1136-1152.

Hu, H.H., Chaney, R.W., 1938. A Miocene flora from Shantung Province, China Part 1. Introduction and systematic considerations. Paleontologica Sinica, 1: 1-82, pls. $1-50$.

Huzioka, K., 1943. On some fossil involucres of Ostrya and Carpinus from the Miocene deposits of Hokkaido and Tyosen. Journal of the Geological Society of Japan 50(602), 317-325.

Huzioka, K., 1964. The Aniai flora of Akita Prefecture and the Aniai-type floras in Honshu, Japan. Journal of the Mining College, Akita University, ser. A, $3(4), 1-105$, pls. $1-18$.

Huzioka, K., 1972. The Tertiary Floras of Korea. Journal of Mining College, Akita University, ser. A, 5(1), 1-83, pls. 1-14.

Huzioka, K., Nishida, S., 1960. The Seki flora of Island of Sado, Japan. Publication of Sado Museum 3, 1-26, pls. $1-7$.

Huzioka, K., Uemura, K., 1973. The Late Miocene Miyata flora of Akita Prefecture, Northeast Honshu, Japan. Bulletin of the National Science Museum 16(4), 661-738, pls. 1-18.

Huzioka, K., Uemura, K., 1974. The Late Miocene Sanzugawa Flora of Akita Prefecture, Northeast Honshu, Japan. Bulletin of the National Science Museum 17(4), 325-366, pls. 1-11.

Imanishi, S., 1956. Explanatory text of the geological map of Japan, Scale 1:50000, Nayoro (Asahikawa-32) Geological Survey of Hokkaido, Sapporo. [in Japanese with English summary].

Kato, M., Ebihara, A., (eds). 2011. Endemic Plants of Japan, Tokai University Press, Hatano, Kanagawa. [in Japanese].

Kramer, K.U., Green, P.S., (eds). 1990. Pteridophytes and Gymnosperms, Springer-Verlag.

Kunzmann, L., 2012. Early Oligocene riparian and swamp forests with a mass occurrence of Zingiberoideophyllum (extinct Zingiberales) from Saxony, Central Germany. Palaios 27, 765-778. 
Miki, S., 1941. On the change of flora in Eastern Asia since Tertiary period (I). The clay or lignite beds flora in Japan with special reference to the Pinus trifolia beds in Central Hondo. Japanese Journal of Botany 11, 237-303.

Narita, A., Uemura, K., Matsumoto, M., Yabe, A., 2012. Middle Miocene megafossil flora from Konan, northwestern part of Shibetsu City, Hokkaido, Japan. Fossils, the Palaeontological Society of Japan 92, 5-18. [in Japanese with English summary].

Narita, A., Yabe, A., Matsumoto, M., Uemura, K., 2017. Paleo-vegetation analysis of the Miocene plant megafossil assemblages from Kaminayoro of Shimokawa Town, Hokkaido, Japan. Journal of the Geological Society of Japan 123(3), 131-145. [in Japanese with English summary].

Nathorst, A.G., 1883. Contributions a la Flore Fossile du Japon. Kungliga Svenska Vetenskapsakademiens Handlingar 20(2), 1-91, pls. 1-16.

Nathorst, A.G., 1888. Zur Fossilen Flora Japan's. Palaeontologische Abhandlungen 4(3), 197-250, pls. 17-30.

Ogasawara, K., Uemura, K., 2006. History of the Japanese Islands and origin of their faunas and floras: 60-78. In: Uemura, K., et al. (Ed.), Natural History of the Japanese Islands, Tokai University Press, Hatano, Kanagawa. [in Japanese].

Oka, T., 1994. Geology and Underground Resources of Naroyo City Geological Survey of Hokkaido, Sapporo. [in Japanese].

Okutsu, H., 1940. Fossil plants from the Nenoshiroishi plant beds near Sendai (I). Saito-Ho-on Kai Museum Research Bulletin 19, 153-169, pls. 7-14.

Okutsu, H., 1955. On the stratigraphy and paleobotany of the Cenozoic plant beds of the Sendai Area. The Science Reports of the Tohoku University, ser, $2,26,1-114$, pls. $1-8$.

Ozaki, K., 1991. Late Miocene and Pliocene floras in central Honshu, Japan Kanagawa Prefectural Museum, Yokohama.

Pavlyutkin, B.I., 2005. The Mid-Miocene Khanka Flora of the Primorye Dalnauka, Vladivostok. [in Russian with English summary].

Pavlyutkin, B.I., Yabe, A., Golozoubov, V.V., Simanenko, L.F., 2016. Miocene floral changes in the circum-Japan Sea areas - their implications in the climatic changes and the time of Japan Sea Opening. Memoirs of the National Museum of Nature and Science 51, 109-123.

Saporta, G., 1888. Dernières adojonctions a la flore fossile d'Aix-en-Province. Annales des sciences naturelles. Botanique, sér. 7, 7, 1-104, pls. 1-10.

Shibata, K., Sato, H., Nakagawa, M., 1981. K-Ar ages of Neogene volcanic rocks from the Noto Peninsula. Journal of the Japanese Association of Mineralogists, Petrologists and Economic Geologists $76,248-252$

Shibata, K., Tanai, T., 1982. K-Ar age of Tertiary volcanic rocks in the Hokkaido. Problems on Neogene
Biostratigraphy of Hokkaido, Research Correspondence Paper 1, 81-90. [in Japanese, original title translated].

Shimizu, Y., 2014. Process of the formation of Japanese forest and typification of vegetation zone - From an East Asian viewpoint. Studies in Regional Science 27, 19-75. [in Japanese with English summary].

Suzuki, K., 1959. On the flora of the upper Miocene Tennoji Formation in the Fukushima Basin, Japan, and its palaeoecological aspect. Monograph of the Association of the Geological Collaboration, 9, 1-49, pls. 1-5.

Suzuki, N., 1963. Late Tertiary maples from northeastern Hokkaido, Japan. Journal of the Faculty of Science, Hokkaido University, ser. 4, 11(4), 683693, pls. $1-5$.

Taira, A., 1990. The Birth of the Japanese Island. Iwanami Shoten, Publishers, Tokyo. [in Japanese].

Takahashi, K., Osanai, H., Matsushita, K., Mitani, K., Nakamura, K., 1971. Explanatory text of the geological map of Japan, Scale 1:50000, Fukinodai (Asahikawa-31) Hokkaido Development Agency, Sapporo. [in Japanese with English summary].

Tanai, T., 1952. Des Fossiles vegetaux dans le bassin houiller de Nishitagawa, Prefecture de Yamagata, Japon. Japanese Journal of Geology and Geography $22,119-135$, pls. 4-5.

Tanai, T., 1955. Illustrated catalogue of Tertiary plants in Japanese coal fields. Report of Geological Survey of Japan 163, 1-16, pls. 1-22.

Tanai, T., 1961. Neogene floral change in Japan. Journal of the Faculty of Science, Hokkaido University, ser. 4, 11(2), 119-398, pls. 1-32.

Tanai, T., 1971. The Miocene Sakipenpetsu Flora from Ashibetsu Area, Central Hokkaido, Japan. Memoirs of the National Science Museum, Tokyo, 4, 128-172.

Tanai, T., 1978. Taxonomical investigation of the living species of the genus Acer L., based on vein architecture. Journal of the Faculty of Science, Hokkaido University, ser. 4, 18(3), 243-282.

Tanai, T., 1983. Revisions of the Tertiary Acer from East Asia. Journal of the Faculty of Science, Hokkaido Imperial University, ser. 4, 20(4), 291-390.

Tanai, T., 1992. Tertiary vegetational history of East Asia. Bulletin of the Mizunami Fossil Museum 19, 125-163. [in Japanese with English summary].

Tanai, T., Onoe, T., 1959. A Miocene flora from the northern part of the Joban coal field, Japan. Bulletin of the Geological Survey of Japan 10, 261-286.

Tanai, T., Onoe, T., 1961. A Mio-Pliocene flora from the Ningyo-toge area on the border between Tottori and Okayama Prefectures, Japan. Report of the Geological Survey of Japan 187, 1-63, pls. 1-18.

Tanai, T., Suzuki, N., 1965. Late Tertiary floras from Northeastern Hokkaido, Japan. Palaeontological Society of Japan, Special Papers (10), 1-117, pls. $1-21$. 
Tanai, T., Ozaki, K., 1977. The genus Acer from the Upper Miocene in Tottori Prefecture, western Japan. Journal of the Faculty of Science, Hokkaido Imperial University, ser. 4, 17(4), 575-606.

Tanai, T., Sato, S., Nakasuji, H., 1981. Late Neogene floral stratigraphy in the Bifuka-Utanobori area. Problems on Neogene Biostratigraphy of Hokkaido, Research Correspondence Paper 1, 38-43. [in Japanese; original title translated].

Tanai, T., Sato, S., Nakasuji, H., 1992. Neogene stratigraphy in the western part of Bihuka-cho, Northcentral Hokkaido. Memoirs of the National Science Museum, Tokyo, 25, 23-32.

Tateishi, M., Kumagai, T., Suyama, Y., Hiura, T., 2010. Differences in transpiration characteristics of Japanese beech trees, Fagus crenata, in Japan. Tree Physiology 30(6), 748-60.

Tsukagoshi, M., 2011. Recent progress in paleobotanical and geological studies of Pinus trifolia flora. Japanese Journal of Historical Botany 19, 15-24.

Tsutsumi, Y., 2014. An Illustrated Guide to Birth of the Japanese Islands Kodansha, Tokyo. [in Japanese].

Uemura, K., 1988. Late Miocene floras in Northeast Honshu, Japan. National Science Museum, Tokyo.

Uemura, K., 1989. Stratigraphic correlation, paleobotany and paleogeographical significance of the lower green-tuff strata around the Japan Sea area. Report of the Grants-in-Aid for Scientific Research by Ministry of Education, 1-41. [in Japanese].

Uemura, K., 1991. Middle Miocene plant megafossil assemblages from the Onnebetsu and Niupu in the Nayoro area, Hokkaido. Memoirs of the National Science Museum 24, 17-26, pls. 1-3. [in Japanese with English summary].

Uemura, K., 2000. Middle Miocene plants from Heigun-to Island, Yamaguchi Pref., southwestern Japan. Memoirs of the National Science Museum 32, 39-54. [in Japanese with English summary].

Uemura, K., 2004. Miocene plant fossils from Nonosawa in Tadami Town, Fukushima Prefecture, Northeast Japan. In: Tadami Town Board of
Education (ed.), History of Tadami Town, Komeya Bookstore, Tadami. [in Japanese], pp. 61-74.

Uemura, K., Yasuno, T., 1991. Miocene plants from the Komegawaki Formation, Fukui Prefecture, central Japan. Professor Shizuka Miura Memorial Volume, 43-54.

Unger, F.J.A.N., 1850. Genera et species plantarum fossilium Wilhelmum Braumüller, Vindobonae.

Wing, S.L., Greenwood, D.R., 1993. Fossils and fossil climate: the case for equable continental interiors in the Eocene. Philosophical Transaction of Royal Society London, B, 341, 243-252.

Wolfe, J.A., 1979. Temperature parameters of humid to mesic forests of Eastern Asia and relation to forests of other regions of the Northern Hemisphere and Australasia. U. S. Geological Survey Professional Paper 1106, 1-36.

Wolfe, J.A., 1995. Paleoclimatic estimates from Tertiary leaf assemblages. Annual Review of Earth and Planetary Sciences 23, 119-142.

Wolfe, J.A., Uemura, K., 1999. Using fossil leaves as paleoprecipitation indicators: An Eocene example: Comment and Reply. Geology.

Yahata, M., 1994. Hot spring gold deposit in the Seta area, Hokkaido, Japan. Chishitsu News 480, 34-43. [in Japanese].

Yanagisawa, Y., Akiba, F., 1998. Refined Neogene diatom biostratigraphy for the northwest Pacific around Japan, with an introduction of code numbers for selected diatom biohorizons. Journal of the Geological Society of Japan 104(6), 395-414.

Yonesaka, M., Yamamoto, J., 2004. Maple leaves similar to Acer carpinifolium Sieb. et Zucc. from the Lower Oligocene Shirakawa Formation (Kobe Group) in Kobe City, Hyogo Prefecture, Japan. The Journal of the Society of Earth Scientists and Amateurs of Japan 53(1), 21-28. [in Japanese].

Yoshiyama, H., Ishikawa, M., 2005. Illustrated reference book of fallen leaves. Bun-ichi Sogo Shuppan, Tokyo. [in Japanese, original title translated] 